\title{
On the role of individuals in models of coupled human and natural systems: lessons from a case study in the Republican River Basin
}

Paul H. Noël

Ximing Cai*

\begin{abstract}
In models of coupled human and natural systems (CHANS), the role of individuals and human behavior is often overlooked as data are scarce and assumptions hard to verify. To assess this role, we couple an agent-based model simulating farmers' behavior and a groundwater model and apply the models to the case of groundwater-fed irrigation in a river basin in the High Plains Aquifer region. Results show the crucial role of human behavior in driving the interactions between these coupled systems. Conversely, individuals are impacted by the systems' dynamics in different ways depending on physical, economic and social characteristics. The findings provide implications for local policy making and education and demonstrate that assumptions on human behavior could be treated as an additional source of uncertainty. This work suggests that modeling individuals and human behavior can be an important step to simulate and understand the dynamics of CHANS in a holistic way.
\end{abstract}




\section{Keywords}

26 Coupled human and natural systems; human behavior; irrigation; agent-based modeling; High Plains

27 Aquifer

28

\section{Introduction}

Climate change, deforestation, disappearing lakes and seas and other large-scale environmental issues, such as the hypoxia zone in the Gulf of Mexico, demonstrate that the Earth has moved into the Anthropocene: an age where humans are the main driver of environmental and ecological changes (Crutzen, 2006; Steffen et al., 2011). This realization has prompted scientists to create a new form of science focusing on coupled human and natural systems (CHANS). This science has been growing steadily over the past 15 years (Liu et al., 2007; Alberti et al., 2011) and advocates for integrated assessment of human and environmental systems. There have also been a number of frameworks and subfields that have emerged in this area to study specific CHANS such as socio-hydrology (Sivapalan et al., 2012), social-ecological systems (Schlüter et al., 2012), hydro-economic systems (Cai, 2008; Harou et al., 2009), integrated environmental modeling (Laniak et al., 2013) and others. The science of CHANS calls for interdisciplinary collaboration and systematic modeling of both human and natural systems to reveal the complex dynamics at stake in such coupled systems.

Models of CHANS are designed to integrate both human and environmental dynamics in order to analyze the co-evolution of human and natural systems (Gual and Norgaard, 2010; Laniak et al., 2013). In the past few decades, environmental models have become more and more complex due to improved computing power and improved quality of data, both spatially and temporally. The inclusion of the human component in environmental models is a more recent effort which is still in its infancy. While progress has been made and new tools have been adopted to develop more integrated environmental models (Kelly et al., 2013), much challenging work is still needed to properly represent human behavior and human influence in these models (An, 2012). One of the main challenges is the validation of such models due to 
the lack of data and understanding of human behavior (An, 2012; Ligtenberg et al., 2010). Moreover, little is known on the effects of human activities to the performance of complex systems such as watersheds or river basins and very few studies have systematically evaluated the impacts of complex human behavior on CHANS (Huang et al., 2013).

It is often not straightforward to decide what model to use for a human system. Various tools have been developed in social sciences (Lave and March, 1993), economics (Tesfatsion, 2003), psychology (Gluck and Pew, 2006) and other fields but no model has been universally accepted across all disciplines as the best way to model human behavior. One modeling approach however has been regularly cited as being particularly effective for simulating CHANS: agent-based modeling (ABM). An (2012) provides a review of agent-based models (ABMs) used to model human decisions in CHANS, which identifies 121 publications applying ABM to CHANS as of 2011, mainly in the fields of ecology and geography. Kelly et al. (2013) identify ABM as one of the five most common approaches that have been used for integrated environmental assessment and management. In the field of social-ecological systems the use of ABMs is particularly prevalent, as illustrated by Rounsevell et al. (2012), Schlüter et al. (2012) and Filatova et al. (2013). ABMs have also been used to study agricultural and water resources systems by modeling different types of water users such as domestic users (Athanasiadis et al., 2005; Galán et al., 2009), water users in river basins (Schlüter and Pahl-Wostl, 2007; Yang et al., 2009 and Yang et al., 2011), irrigators (Arnold et al., 2014; Berger and Troost, 2014) and farmers (van Oel et al., 2010). These studies show that $\mathrm{ABM}$ is a promising, and in some fields well-established, tool to study the interactions between humans and the environment.

Managing water resources systems is usually incredibly difficult not only because of the variability and uncertainty related to climate and hydrology, but also because of the uncertainty and variability related to water demand. The study of individual behavior is particularly important in the field of water demand management. Most water resources systems are dedicated to individuals that need water such as household owners, farmers, fishermen, or users of recreational bodies of water. Understanding these users 
74 is therefore a key component of sound management and policy, especially when water is scarce and 75 conservation becomes a major concern. Jorgensen et al. (2009), for example, present an integrated model 76 to better understand household water use behavior. They find that interpersonal and institutional trust are 77 crucial factors of household water consumption behavior, even though such behavioral characteristics of 78 individuals are overlooked in most studies. Russell and Fielding (2010) go even further by studying the 79 psychology of water users in order to understand water conservation behavior. They identify five causes 80 of residential water conservation behaviors: attitudes, beliefs, habits or routines, personal capabilities, and 81 contextual factors. These two examples illustrate the importance of understanding individual behavior to 82 study water demand patterns so as to devise better policies for water conservation. What is true for 83 residential water management holds for irrigation management too. Irrigation varies in space and time and 84 from farmer to farmer. Sauer et al. (2010) show that irrigation development and practices have impacts 85 even at the global scale.

Few studies have shown the role of individuals in CHANS, especially when these studies were 87 designed for water resources systems analysis (An, 2012). Our study is an attempt to understand how 88 individuals matter in modeling CHANS and what can be learned from modeling the human system at the 89 individual level. We address these questions using an integrated ABM and a groundwater model. It 90 should be noted that it is not necessary to use an ABM to simulate a CHANS, as one could focus on the 91 properties of the system, where the microscale interactions may not be important for the study purpose, as 92 seen in many modeling efforts (Laniak et al., 2013). Under some conditions implementing an ABM is not 93 feasible, especially when data required for modeling individuals are hard to obtain because of ethics or 94 other reasons preventing data collection (Filatova et al., 2013). In this paper, we choose to use an ABM 95 because it is a natural framework to model individuals, especially human agents in the human dimension 96 of CHANS. The heterogeneity of the individual behaviors affects the emerging performance of the 97 system. In the ABM, individual farmers are defined as agents who make daily decisions on groundwater 98 use to irrigate cash crops and earn profits. The ABM also includes an agent representing a regulatory 
agency that monitors water levels and implements water-conservation regulations. The human behavior of an agent is considered as a variable in the ABM. Human behavior heterogeneity is an important characteristic of water users in general although it is difficult to measure and quantify. Two farmers with crop fields in the same physical conditions (i.e., soil type, climate, well yield, etc.) could still make different irrigation decisions following their experience, their perception of risk and other factors. Among the studies of agent-based models on agriculture and agricultural water management issues, Berger (2001) introduced diversified technology adoption behaviors among farms, and using a human behavior parameter on the various thresholds to technology adoption to quantify the human behavior heterogeneity associated with physical heterogeneity of farms. A more recent study by Baggio and Janssen (2013) tested various behavioral theories (i.e. with experimental data of irrigation games). For a review of relevant studies with more detailed discussion on human behavior representation in an ABM, readers should refer to Kremmydas, (2012) and Elsawah et al., (2015).

In this framework, farmers and institutions form the human component of the system, rivers and the aquifer form the natural component of the system, and the two coupled systems interact through irrigation, water conservation, and regulations with influence of external factors such as climate and crop market. We show that these two models coupled together and validated for in a watershed of the Republican River Basin (RRB) in Nebraska illustrate the importance of including individuals and human behavior in modeling CHANS. It is important to note that researchers working at the individual level may need to consider ethical integrity when any non-publicly available data are used.

Our work is related to several recent studies, which share a similar context (i.e., connecting agriculture, economics and groundwater) and modeling approach with ours. Castilla-Rho et al. (2015) developed FlowLogo to help researchers develop coupled agent-based groundwater models. It is an interactive modelling environment that allows users to explore how patterns of groundwater movement and social development can emerge from agents' behavior and their interactions. Bulatewicz et al. (2010) use the Open Modeling Interface to integrate models of agriculture, economics and groundwater and 

applied the methodology to Sheridan County in Kansas located above the High Plains Aquifer. Condon and Maxwell (2014) present an integrated hydrologic model to study the spatial and temporal patterns caused by feedbacks between irrigation and water availability in the Little Washita Basin in Southwestern Oklahoma, USA. Foster et al. (2014) introduce a new modeling approach of irrigation behavior in groundwater systems. Their modeling approach incorporates the impacts of well yield and climate on crop production and water use to determine irrigation demand. Mulligan et al. (2014) present a model which couples an agent-based model of farmers' irrigation behavior with a groundwater model to study a subwatershed of the RRB. We share a similar modeling approach or have a similar study area as these four studies, but what makes our work unique is that we assess the importance of individuals and their behavior in modeling CHANS.

In the rest of this paper, the modeling framework is presented in section 2 and its application to an area located in the RRB is presented in section 3. Results are then described and explained in section 4. Additional discussion on the importance of representing individuals in CHANS and conclusions are provided in section 5 .

\section{Methodology}

\subsection{The modeling framework}

The structure of the modeling framework is shown in Figure 1. The ABM and the hydrologic 141 model interact through two variables: farmers' daily pumping decisions for irrigation (from the ABM to 142 the groundwater model) and water table (from the groundwater to the $A B M$ ). The ABM is subject to 143 external economic drivers such as fuel and corn prices and both models are subject to external climate 144 drivers such as precipitation and evapotranspiration. Coupled together, the two models are able to 145 simulate irrigation decisions and their impacts on groundwater depletion over a long period of time. 


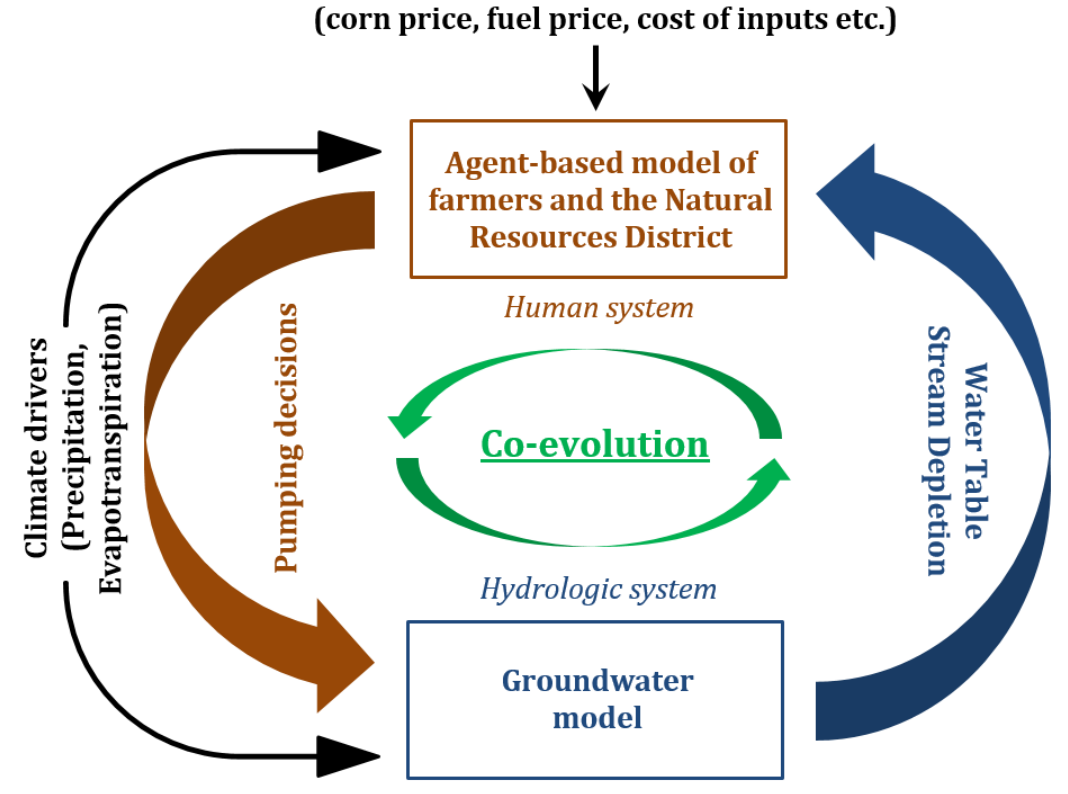

Macro-economic drivers (corn price, fuel price, cost of inputs etc.)

Figure 1: Structure of the modeling framework

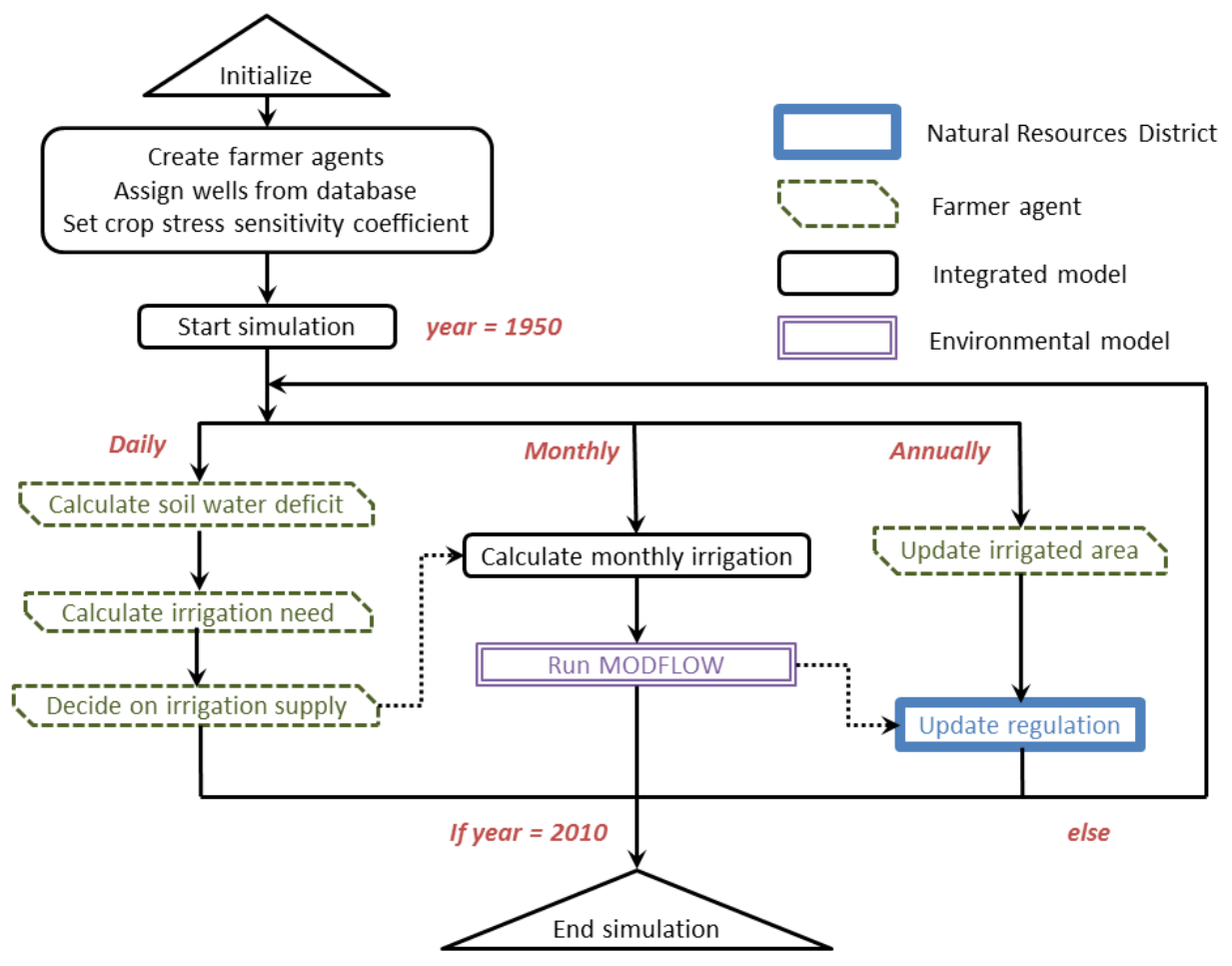

Figure 2: Flow Chart of the integrated models 
The integrated model is structured as follows (Figure 2). Farmers make daily decisions on the amount of irrigation to apply to their fields based on soil water deficit. These daily pumping decisions are aggregated monthly and used as input for the groundwater model. The groundwater model runs every month and provides updated water-table and baseflow values to the ABM. Every year, the regulatory agent makes decisions on irrigation regulations based on streamflow depletion. Every year, farmers also make decisions on their irrigated surface based on long-term potential and actual evapotranspiration. The $\mathrm{ABM}$ is initialized and then runs at a daily time step with actions performed at the daily, monthly and annual time steps. The groundwater model runs at a monthly time step as it is the bottleneck in terms of computation time. This time scale allows the model to reasonably capture the water-table drop during the growing season. Both models are described in more details in the next two sections. Noël (2015) also describes the model and provides a standardized description following the ODD+D protocol (Müller et al., 2013) which is also included in the supplementary material.

imposed on all farmers. For example, if baseflow drops under the threshold of $200 \mathrm{ft}^{3} / \mathrm{day}$ in 1978 , the

There are two types of agents defined in the ABM: a number of farmers and one regulatory agency (a Natural Resources District (NRD) in this study). The NRD agent sets up regulations when the flux of water from the aquifer to the streams - used as a proxy for baseflow - drops under some thresholds. While this model does not simulate streamflow directly, baseflow is a portion of streamflow that comes from groundwater seeping into the streams. Regulatory agencies often implement regulations based on streamflow (Republican River Compact Administration). These thresholds were calibrated to ensure that the regulation decisions made by the NRD agent in a historical simulation approximately match in time the actual regulation implementations in Nebraska (also see the presentation of the case study in section 3.1). Each regulation is a cap on the annual amount of irrigation withdrawal that is NRD agent sets a first irrigation cap of 22 inches per year. 


\section{Table 1: Variables and Parameters in model}

\begin{tabular}{|c|c|c|}
\hline Variables and Parameters & Name & Units \\
\hline$A$ & Acreage of field & acre \\
\hline$A I$ & Annual irrigation depth & inch \\
\hline$A_{w}$ & Acreage of field irrigated by well $\mathrm{w}$ & acre \\
\hline$A W C$ & Available Water Capacity of the root zone & inch of water/inch of soil \\
\hline$C P$ & Corn price & \$/bushel \\
\hline$C Y$ & Crop yield & bushel/acre \\
\hline$C Y_{\max }$ & Maximum or potential crop yield (increases over the years) & bushel/acre \\
\hline$C Y_{w}$ & Crop yield at well $\mathrm{w}$ & bushel/acre \\
\hline$D C$ & Diesel cost & \$/gallon \\
\hline$\Delta A$ & Reduction of irrigated area & acre \\
\hline$d_{M A D}$ & Managed allowed deficit & inch \\
\hline$D_{r z}$ & Depth of the root zone (varies during growing season) & inch \\
\hline$E^{*}$ & Threshold relative ET & - \\
\hline$E T$ & Corn evapotranspiration & inch \\
\hline$E T_{0}$ & Reference or potential evapotranspiration & inch \\
\hline$F C$ & Fixed costs & \$/acre \\
\hline$H D C$ & Harvesting and drying cost & \$/bushel \\
\hline$I D$ & Irrigation demand & inch \\
\hline$I E$ & Irrigation efficiency & $\%$ \\
\hline$I S$ & Irrigation supply & inch \\
\hline$k_{c}$ & Crop coefficient for corn (varies by crop growth stage) & - \\
\hline$k_{s}$ & Crop water stress coefficient & - \\
\hline$k_{y}$ & Crop yield coefficient for corn (varies by crop growth stage) & - \\
\hline$M A D$ & Managed allowed deficit & $\%$ \\
\hline$P$ & Precipitation & inch \\
\hline$P C_{w}$ & Pumping cost at well $\mathrm{w}$ & $\$$ \\
\hline$P E$ & Pump performance & horsepower.hour/gallon \\
\hline$P P$ & Pumping pressure & psi \\
\hline$P R$ & Pumping rate & gallon/minute \\
\hline$R$ & Irrigation cap or regulation & inch \\
\hline$S C$ & Coefficient of sensitivity to crop water stress & - \\
\hline
\end{tabular}




\begin{tabular}{clc}
\hline$S W D$ & Soil water deficit & inch \\
\hline$S W D_{p}$ & Soil water deficit on previous day & inch \\
\hline$T A W$ & Total available water & inch \\
\hline$T O$ & Time of operation & hour/day \\
\hline$W D$ & Water depth in the well & feet \\
\hline$W Y$ & Well yield & gallon/minute \\
\hline$Y R$ & Yield ratio & - \\
\hline
\end{tabular}

188 Each day, it is assumed that farmers know soil water deficit at each of their fields (via soil moisture 189 sensors or validated model simulation) and use this information to decide if and how much to irrigate as 190 described by equations (1) and (2):

$$
\begin{gathered}
I D=S W D-d_{M A D} \\
S W D=S W D_{p}+E T-P-I S
\end{gathered}
$$

191 where $I D$ is the irrigation demand, $S W D$ is the soil water deficit and $d_{M A D}$ is the managed allowed deficit 192 (all in inches). If $S W D$ is smaller than $d_{M A D}$, irrigation requirement is then set to $0 . S W D_{p}$ is the soil water 193 deficit from the previous day, ET is the corn evapotranspiration, $P$ is the precipitation and $I S$ is the 194 irrigation supply (all in inches). ET is calculated using the equation below:

$$
E T=k_{c} \times k_{s} \times E T_{0}
$$

195 where $E T_{0}$ is the reference evapotranspiration, $k_{c}$ is the crop coefficient for corn which varies with crop 196 development stages and $k_{s}$ is a water stress coefficient varying between 0 and 1 (both coefficients are 197 dimensionless). $k_{s}$ is estimated based on a simple equation using $S W D$, the total available water $T A W$ (in 198 inches), and the managed allowed deficit (in \%) MAD:

$$
k_{s}=\frac{T A W-S W D}{(1-M A D) * T A W}
$$

199 The total available water is simply the product of the available water capacity of the root zone $A W C$ (inch 200 of water/inch of soil) with the total depth of the root zone $D_{r z}$ (inches). $A W C$ is a characteristic of the soil. $201 D_{r z}$ varies during the crop growth season. 


$$
T A W=A W C \times D_{r z}
$$

Equations (1) to (5) are adapted from Allen et al. (1998) and Andales et al. (2011). After daily irrigation demand is calculated, farmers calculate daily irrigation supply for each active well. Irrigation Supply $(I S)$ is restricted by well yield and the annual irrigation water use permit. It is assumed that a well can only be pumped for a time of operation (TO) of 20 hours per day (Merkley and Allen, 2004). Knowing the acreage $A$ of each field and the irrigation efficiency (IE) assumed to be $90 \%$ in the model - a typical value for center-pivot, it is possible to calculate the necessary pumping rate $(P R)$ (in gallons per minute) and then obtain $I S$ depending on whether $P R$ is above or below the well yield (WY) in gallons per minute which is taken from the well database used in the case study:

$$
\begin{gathered}
I S=\left\{\begin{array}{l}
I D \quad \text { if } P R<W Y \\
0.0022 \times T O \times \frac{W Y}{A} \quad \text { if } P R \geq W Y
\end{array}\right. \\
P R=\frac{I D \times A}{0.0022 \times T O \times I E}
\end{gathered}
$$

210 in which 0.0022 is a unit conversion factor. IS is then updated based on the annual amount of irrigation $211(A I)$ on the current day of the simulation, which is the cumulative amount of water used for irrigation until 212 this day during this growing season, and the regulation $R$ currently followed by the farmer (both in inch) 213 as described in Equation (8) below. This means that the farmer stops irrigating once the cumulative 214 annual irrigation reaches the annual irrigation cap. Farmers in the model do not do long-term planning 215 ahead of the season. While real farmers attempt to conduct long-term planning, it is still a challenge for 216 them to know ahead of a growing season if it will be a dry or wet year (Shafiee-Jood et. al., 2014).

$$
I S= \begin{cases}I S & \text { if } A I+I S \leq R \\ 0 & \text { otherwise }\end{cases}
$$

In our study, farmers' behavior is differentiated through the introduction of a coefficient characterizing their sensitivity to crop water stress (SC), following the work of Miro (2012). This 
coefficient is used to modify farmers' managed allowed depletion (MAD). Recommended values of MAD are usually provided for each stage of a crop growth season. Equation (9) redefines managed water deficit 221 (Allen et al., 1998; Andales et al., 2011) in inch $\left(d_{M A D}\right)$ by considering the impact of $S C$.

$$
d_{M A D}=\frac{M A D}{100} \times T A W * S C
$$

If $S C$ is set to 1 , it means that the farmer will follow the recommended values of $M A D$; otherwise 223 it means that the farmer will be less (when $S C>1)$ or more $(S C<1)$ sensitive to crop water stress. If $S C$ is 224 close to zero for example, $d_{M A D}$ will be very low which means that the farmer will irrigate very often. At 225 the end of the growing season the crop yield $(C Y)$ is estimated by

$$
C Y=C Y_{\max } \times Y R
$$

226 where $C Y_{\max }$ is calculated with an empirical equation (11), which is calibrated against corn yield data 227 from the United Stated Department of Agriculture (USDA) and accounts for the increase of maximum 228 corn yield with time due to improving agricultural practices (USDA, 2013):

$$
C Y_{\text {max }}= \begin{cases}4 \times n+76.937 & \text { if } n \leq 38 \\ 200 \times \log ((n-1) \times 2)-150 & \text { otherwise } .\end{cases}
$$

229 The yield ratio $(Y R)$ is calculated with the following equation (Jensen, 1968):

$$
Y R=\prod_{i=1}^{6}\left(1-k_{y}\left(\frac{E T^{i}}{E T_{0}^{i}}\right)\right)
$$

230 where $i$ denotes the crop growth stage (accounting for 6 stages in this study). Equation (12) shows that the crop yield is reduced when the actual crop evapotranspiration $(E T)$ is inferior to the potential 232 evapotranspiration $\left(E T_{0}\right)$ which happens if precipitation plus irrigation do not provide enough water to the 233 crop. The coefficient $k_{y}$ is a crop coefficient for corn yield that varies per crop growth stage. Finally, the 234 net profit is calculated as: 


$$
P=\sum_{w \in W}\left[(C P-H D C) \times C Y_{w} \times A_{w}-A_{w} \times F C-P C_{w}\right]
$$

235 where $W$ is the ensemble of wells owned by a farmer, $C P$ is the corn price, $H D C$ the harvesting and drying cost, $F C$ is the fixed costs, and $P C_{w}$ is the pumping cost at well w. $P C$ is calculated by:

$$
P C=D C \times P R \times \frac{(W D+2.308 \times P P)}{3960} \times T O \times P E
$$

237 where $D C$ is the diesel cost, $P R$ the pumping rate, $W D$ the water depth in the well, $P P$ the pumping 238 pressure - assumed to be $60 \mathrm{psi}$, TO the time of operation - assumed to be 20 hours - and $P E$ the 239 performance (i.e., the amount of work that can be obtained from a unit of energy) assumed to be 8.75 240 hp.hr/gal for a center-pivot pump. Equation (14) and the values for $P P$ and $P E$ are adapted from Martin et 241 al. (2011).

Farmers' annual decisions on irrigated area are modeled using the framework described by Rosegrant et al. (2002) based on the ratio between actual and potential crop ET averaged over the three previous years. That is to say, each year farmers decide if they should reduce their irrigated acreage or use all the available land depending on the long term water-deficit in their fields. Equation (15) adapted from Rosegrant et al. (2002) estimates the reduction of irrigated area $\Delta A$ in current year $(n)$ assuming a threshold relative ET $\left(E^{*}\right)$ of 0.6 :

$$
\Delta A=A\left[1-\left(\frac{1}{3} \sum_{k=n-3}^{n-1} \frac{E T^{k}}{E T_{0}^{k}} / E^{*}\right)\right]
$$

\section{$248 \quad$ 2.3. The groundwater model}

The groundwater model was developed with MODFLOW (Harbaugh, 2005). MODFLOW uses 250 the finite-difference method to solve the three-dimensional groundwater flow equation for a porous 251 medium and calculate hydraulic head in each rectangular grid cell for each time step. It is a fully 252 distributed numerical program designed for high modularity. The governing equations account for 
hydraulic parameters such as hydraulic conductivity, transmissivity, and specific yield, spatially varying boundary conditions, and other volumetric fluxes such as pumping wells, recharge, and evapotranspiration. In this study, the groundwater model was established to simulate groundwater flow in an area within the RRB (see section 3.1. for the description of the case study). All the data used to develop the model were extracted from the Republican River Compact Administration (RRCA) model (RRCA, 2003). The RRCA model was calibrated to historical water table observations at the various locations throughout the basin. The RRCA model represents both groundwater levels and baseflow in the stream network. The groundwater model developed as part of this integrated model runs with a monthly stress period and water head is calculated 10 times per stress period. It consists of 1 layer and 2,500 grid cells with a size of one square mile per cell. Data from the RRCA model used to develop this model include the top and bottom layers of the aquifer, aquifer properties such as hydraulic conductivity and storativity, stream location and monthly ET. All these data vary spatially and ET also varies temporally. Other time-varying inputs to the model include recharge and pumping rates at wells, both of which are monthly outputs from the ABM. Boundary conditions were created based on water-levels in the predevelopment period calculated in the RRCA model.

\section{Application to the Republican River Basin}

\subsection{Case study area}

The RRB is shared between the States of Colorado, Kansas and Nebraska. The basin's area is 24,900 square miles, located above the High Plains Aquifer, one of the largest aquifers in the world. The economy of the basin is dominated by agriculture and corn is the predominant crop grown in the area. Most of the 8.5 million acres dedicated to agriculture in the region are irrigated by nearly 100,000 wells within the basin (Nebraska Department of Agriculture, 2013). Complex interactions between farmers who irrigate and the environment have shaped both the economics and the hydrology of the region. Decades of extensive groundwater irrigation for cash crop agriculture have depleted both groundwater and surface 


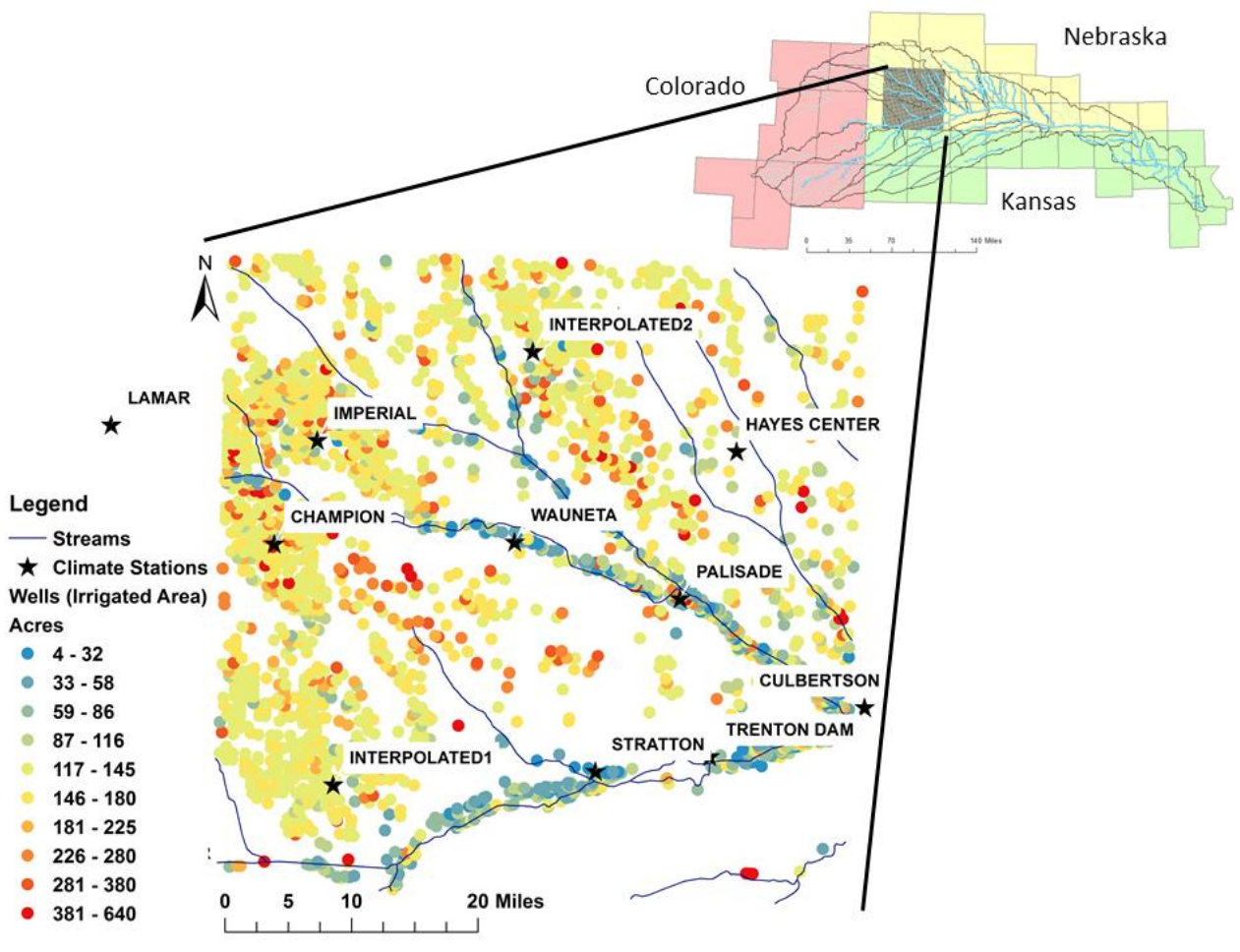

Figure 3: Area of study in the Republican River Basin with pumping wells of various sizes (supporting irrigated field ranging from 4 to 640 acres) 
The region chosen for the case study has an area of 2,500 square-mile (6,475 square-kilometer),

Table 2: Datasets used in the model and their sources

\begin{tabular}{|c|c|c|c|}
\hline Dataset & Model parameters and variables & Source & Link \\
\hline \multirow{2}{*}{ Soil type } & \multirow{2}{*}{ Available water capacity } & \multirow{2}{*}{ STATSGO, Nebraska } & http://water.usgs.gov/GIS/metadata/usg \\
\hline & & & $\underline{\text { swrd/XML/ussoils.xml }}$ \\
\hline $\begin{array}{l}\text { Well } \\
\text { inventory }\end{array}$ & $\begin{array}{l}\text { Well location, Maximum well yield, } \\
\text { Irrigated acres, Well activation date }\end{array}$ & $\begin{array}{l}\text { Nebraska Department of } \\
\text { Natural Resources }\end{array}$ & $\begin{array}{l}\text { http://dnr.nebraska.gov/gwr/registered- } \\
\text { groundwater-wells-data-retrieval }\end{array}$ \\
\hline Crop growth & $\begin{array}{l}\text { Depth or rooting zone, Crop } \\
\text { coefficient, Management allowed } \\
\text { depletion }\end{array}$ & Andales et al., 2011 & \\
\hline Climate & $\begin{array}{l}\text { Daily Precipitation, Daily Potential } \\
\text { Evapotranspiration }\end{array}$ & $\begin{array}{l}\text { High Plains Regional } \\
\text { Climate Center }\end{array}$ & http://www.hprcc.unl.edu/index.php \\
\hline \multirow[t]{3}{*}{ Costs } & Corn prices & $\begin{array}{l}\text { Farmdoc, University of } \\
\text { Illinois Extension }\end{array}$ & $\begin{array}{l}\text { http://www.farmdoc.illinois.edu/manag } \\
\text { e/uspricehistory/us_price_history.html }\end{array}$ \\
\hline & Diesel prices & $\begin{array}{l}\text { U.S. Energy Information } \\
\text { Administration }\end{array}$ & www.eia.gov/ae \\
\hline & $\begin{array}{l}\text { Other costs (fertilizers, pesticides, } \\
\text { labor etc.) }\end{array}$ & $\begin{array}{l}\text { Texas AgriLife Extension } \\
\text { Service }\end{array}$ & http://agrilifeextension.tamu.edu \\
\hline Groundwater & $\begin{array}{l}\text { Top and bottom elevation, Hydraulic } \\
\text { conductivity, storativity, Monthly ET, } \\
\text { Stream network, Initial head }\end{array}$ & $\begin{array}{l}\text { Republican River Compact } \\
\text { Administration (RRCA) }\end{array}$ & $\begin{array}{l}\text { http://www.republicanrivercompact.org } \\
\text { /index.html }\end{array}$ \\
\hline Regulations & Regulations & $\begin{array}{l}\text { Nebraska's Natural } \\
\text { Resources Districts }\end{array}$ & http://nrdnet.org/water.php \\
\hline
\end{tabular}

The scale of the region was chosen so to be small enough to model every individual farmer, yet 303 large enough to model the feedbacks occurring between the human system and the natural system. Figure 3044 shows the increase in irrigated area in the region along with the decrease of annual streamflow a few 305 miles downstream of the outlet of the region. The causal relationship between the two variables illustrates 
the challenges faced by stakeholders in the region in terms of human development and the impact on the environment. Furthermore, Figure 4 partially demonstrates how humans and the environment have been 308 co-evolving over the past hundred years. The human activities include not only active irrigation 309 development but also response to environmental change. For example, in the Upper Republican Natural 310 Resources District, annual irrigation allocations decreased from 20 inches in 1978 to 13.5 inches in 2005 311 (Nebraska Association of Resources Districts, 2014). Other policies have also been implemented such as 312 well spacing regulations, incentives provided to farmers to reduce water consumption, purchasing of 313 formerly irrigated land, and moratoriums on drilling new wells.

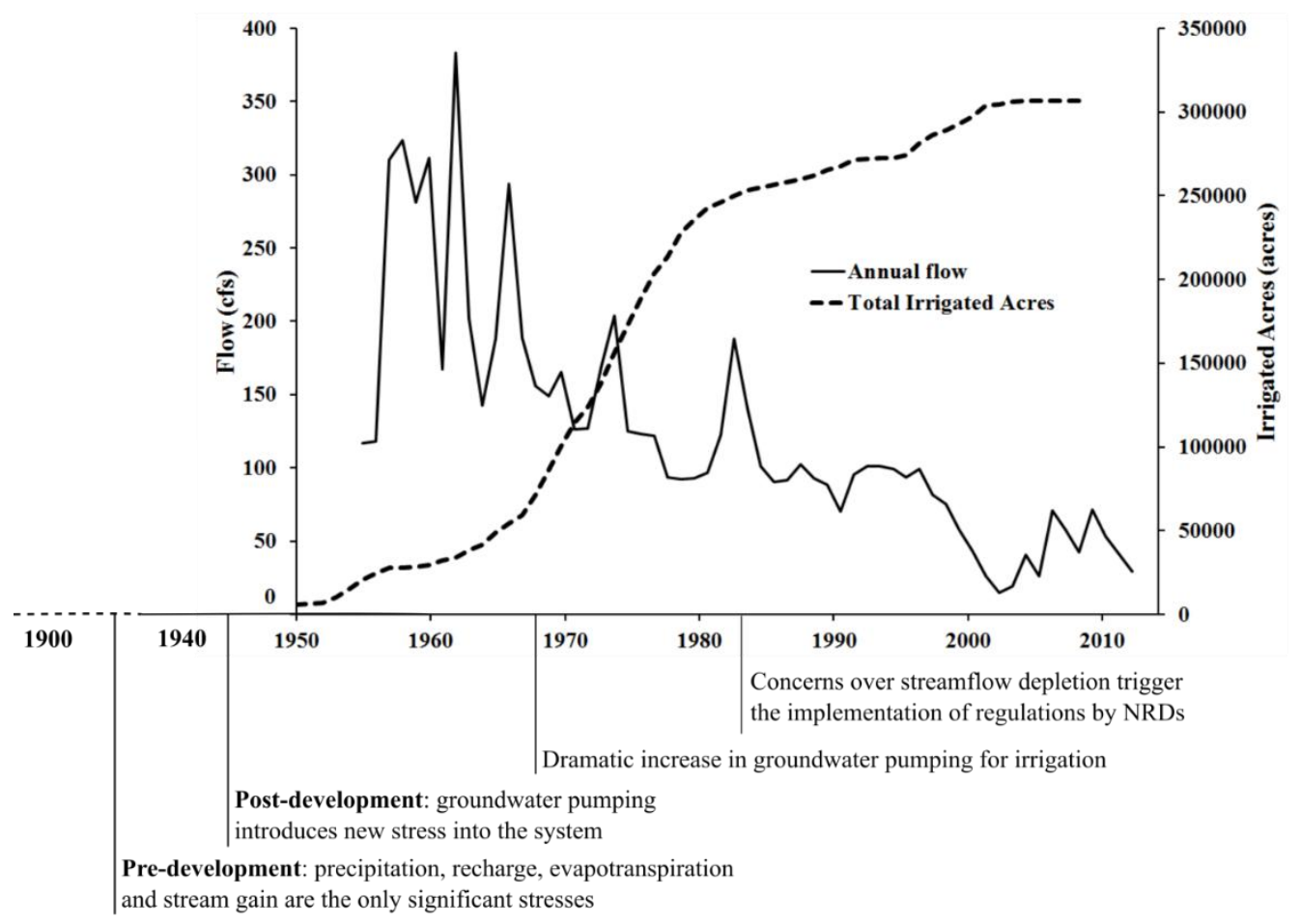

Figure 4: History of irrigation and streamflow depletion in the region

In the $\mathrm{ABM}$, agents are created by dividing the 2,500-square mile study area into grids of 1 317 square-mile and assigning an agent to each square containing one or more pumping wells. The average 318 farm size in Nebraska is 972 acres (Nebraska Department of Agriculture, 2013), which is 1.5 times of the 319 size of an agent in the model - 640 acres. However, the model uses certified irrigated acres from the data 320 on pumping wells to delineate the agents. Thus the crop acreage with one agent (i.e., in each grid) can be 
different from that of others. With this assumption, 1040 agents are delineated in the ABM. Rainfed farming is not considered in this study. For simplicity, this study only considers corn, which represents the predominant crop grown in Nebraska accounting for $82 \%$ of the total cropland in Chase County, $70 \%$ in Dundy County, $51 \%$ in Hayes County and $45 \%$ in Hitchcock County (United States Department of Agriculture, 2013). Corn is also the main irrigated crop representing around 95\% of total irrigated cropland in Hitchcock County for example (United States Department of Agriculture, 2013).

\subsection{Validation of the model}

Although this model is used in an exploratory way to study the importance of individuals in CHANS, it is important to demonstrate that the results obtained with this model are reasonable. In this case, the ideal would be to validate the model against irrigation data. However, irrigation data are usually hard to obtain, especially in the RRB because of on-going law-suits and conflicts (Popelka, 2004) and because farmers are not required to document their water-use (Szilagyi, 1999). Thus, this study only validates a historical or baseline simulation running from 1950 to 2009 using available data. In this historical simulation, all farmers are assumed to have the same behavior and follow the recommended values for $M A D$ (in other words, $S C$ is set to 1 for all farmers). As a first validation, the long-term average irrigation predicted by our model over the region was calculated. The value was 14.1 inches, which is close to the value of 14 inches estimated by University of Nebraska Crop Watch page on Irrigation and Water Management for Corn as the average irrigation need for corn in western Nebraska (Irrigation and Water Management for Corn). The most reliable data that we found for the validation are USDA countylevel historical corn yields, which are available for the entire simulation period (from 1950 to 2009) for the four counties in the area (USDA, 2013). The average reported corn yield for the region during the simulation period is 119.7 bushels per acre. The average simulated corn yield of 120.9 bushels per acre is close to the reported value and the root-mean-square deviation is 23.5 bushels per acre over the 60 years of the simulation with a coefficient of variation is 0.2 , showing that the model performs well in terms of determining the regionally-averaged corn yield. It is worthy of noting that most of the deviation between 
historical and predicted corn yield derives from the processes that are not captured by the model such as crop damages from flooding. For example, the model predicts a high average corn yield of 206 bushels per acre in 1993 whereas yields were actually really low in the region on that year (average of 108.5 bushels per acre) due to the Great Flood of 1993 and related crop damages (Perry and Combs, 1998).

The groundwater model developed for this study was not calibrated, which constitutes a 351 limitation in terms of representing accurately historical groundwater and baseflow levels, although the 352 model is based on the RRCA model which is itself calibrated. The accuracy of the model is sufficient to 353 allow the spatial simulation of distributed impacts of pumping on water head and baseflow for an 354 exploratory analysis. However, reproducing accurately water head in the aquifer is beyond the scope of 355 this paper as the integrated model is developed for an exploratory analysis of the role of individuals and 356 human behavior on CHANS.

\section{4. Results}

To assess the role of individuals in CHANS models, we focus on the coefficient of sensitivity to crop stress $S C$ introduced in equation (9). We run a set of experiments from simple to complex cases by changing $S C$ in different ways to investigate how farmers' responses to water stress and the various levels of heterogeneity with individuals' responses affect and are affected by the system. $S C$ is a key parameter that accounts for a farmer's behavior with regards to personal preferences and irrigation decisions in face of crop water stress, one of the most important factors of irrigation management especially in arid and semi-arid environments (Clarke, 1997; Colaizzi et al., 2003; Ghulam et al., 2008). However, it is difficult to measure this parameter that captures human characteristics. Understanding more thoroughly the role of the human characteristics can help determine the data need for the human dimension in CHANS models. We assess the role of individuals in the system in section 4.1 and their impacts on system dynamics in section 4.2. To further understand the feedbacks between individual behaviors and system dynamics, we 
discuss the role of human behavior heterogeneity in section 4.3 and in section 4.4 , where we analyze behavior adaptation through an additional model experiment.

\section{4.1. Assessing the role of individuals in the system}

In the first experiment, we assess the impacts of individuals on the system-level performance using the historical simulation described in the validation section. In this simulation, the sensitivity coefficient $S C$ is set to 1 for all farmers, which assumes all farmers respond to crop water stress homogenously by adopting the "most accepted" knowledge of water deficits. Figure 5 displays a map of corn yield in bushels per acre at the end of each decade and shows how spatial and temporal corn yield patterns emerge as a result of heterogeneous physical parameters but homogenous behavior parameters $(S C)$. The first visible pattern is the exogenous increase in well density due to the adoption of center-pivot irrigation in the basin from 1950 to 2009 . This pattern appears due to historical data used to determine when farmers will start using irrigation. The second pattern is the exogenous increase of maximum yield from a high of 90 bushels per acre in 1960 to a high of 250 bushels per acre in 2009 due to the improving technology and agricultural practices captured by equation (11). The third pattern is the spatial variability of corn yield caused by heterogeneous well characteristics, soil types and climatic conditions across the area and how this variability also changes with time. The spatial patterns change over time and the zones of high yield and low yield move around over the 60 years of the simulation. However, one area located in the North-West section of the region has consistently the highest corn yield from 1950 to 2009. Even though their behavior is homogeneous, the farmers make their decisions on irrigation based on heterogeneous physical parameters such as soil type, climate or well yield. Similar results were obtained by Condon and Maxwell (2014), who observed spatial and temporal patterns caused by physical heterogeneity of factors affecting farmers' decisions. 

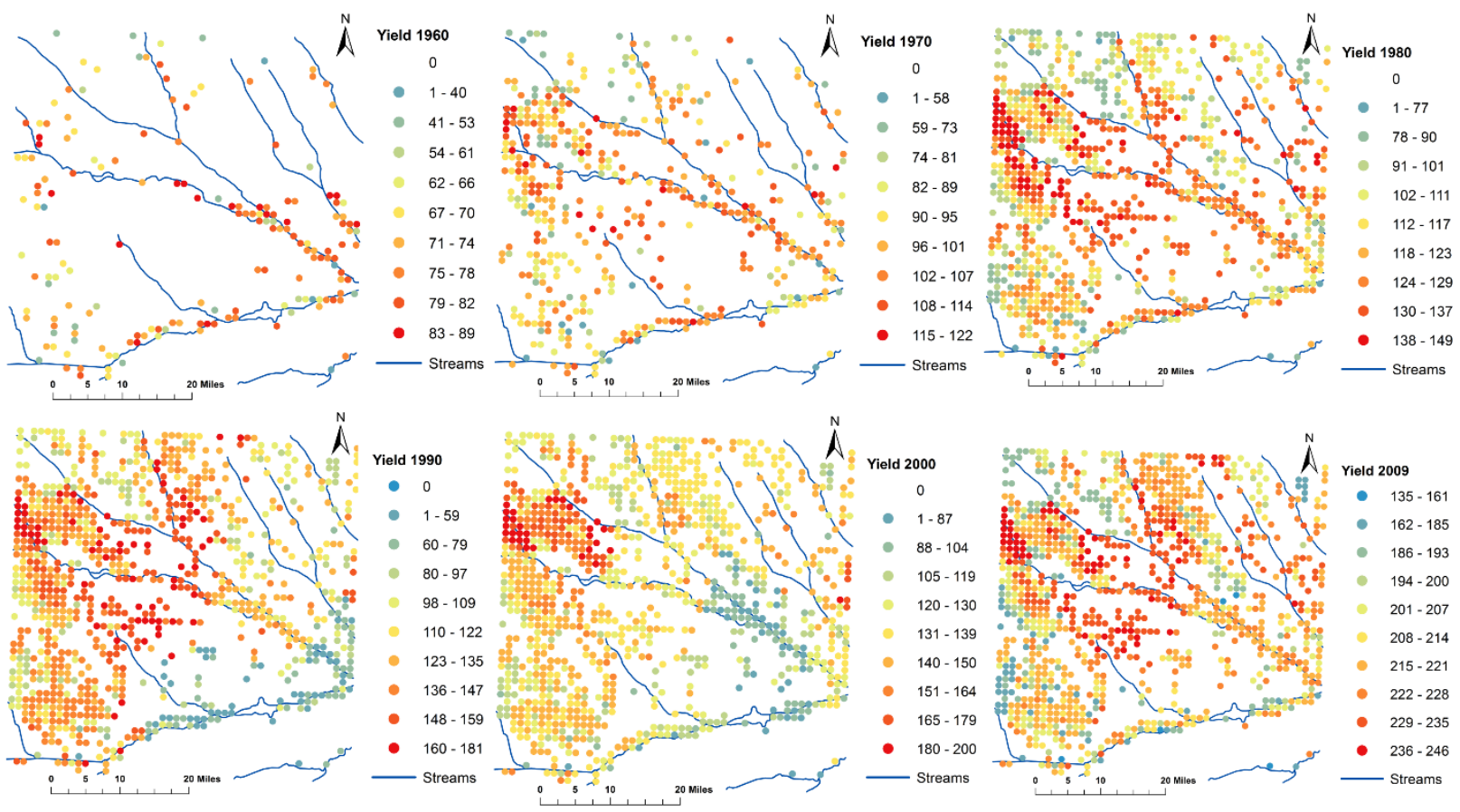

Figure 5: Evolution of corn yield during the 60 years of simulation

In a second experiment, two additional simulations are performed to analyze more specifically the role of "human" behavior: farmers' personal sensitivity to crop water stress. In these two simulations, all farmers were assigned the same value of 0.8 in one case and 1.2 in the other for the sensitivity coefficient $S C$. These two simulations show how the dynamics of the coupled systems would be affected if all the farmers were much more or much less sensitive to crop water stress. Figure 6 shows the results for irrigation, regulation and the flux of water from the aquifer to the streams for the two simulations. As can be expected, when the value of $S C$ is low and farmers are more sensitive to crop stress, annual irrigation is higher than that from the historical simulation where $S C=1$. As a result, streamflow decreases more quickly due to declining baseflow, and NRD implements regulations earlier. In the case of a high $S C$ value where farmers are less sensitive to crop water stress, irrigation rates are significantly lower, causing lower streamflow decline and triggering regulations later. Regulations play a stronger role in the case with high sensitivity to crop water stress as farmers pump up to the limit enforced by the regulations, while the role of regulations is not obvious in the case where farmers are less sensitive to crop water stress and use less water to irrigate their fields. These two simulations show how different human behaviors will affect 

408 water stress could be improved, significant reductions of streamflow depletion could be achieved as 409 shown on Figure 6, keeping in mind that profits would be affected too as shown in the next section.
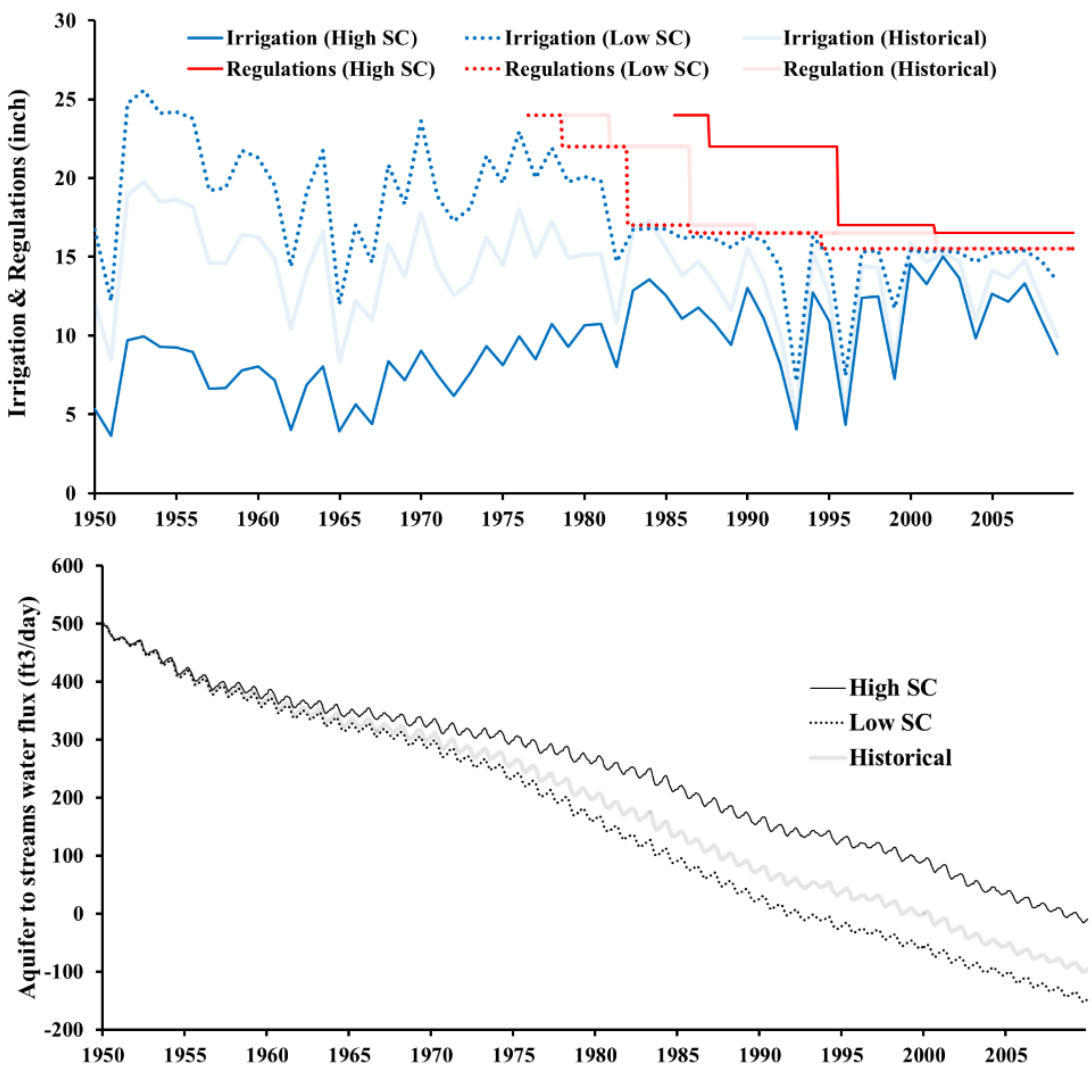

Figure 6: Irrigation, regulations and flux of water from the aquifer to the streams for two simulations with high and low values for the sensitivity coefficient and the historical simulation

Next, we turn to an experiment that illustrates the importance of individual behavior as presented 417 farmers using one realization of a normal distribution with a mean of 1 and a standard deviation of 0.01 . 418 Nine other realizations were used but are not shown here for conciseness and because results were similar 419 to the one shown on Figure 7. The figure shows a box plot of irrigation and blue dots representing the 
average annual precipitation over the region (both in inches). This figure shows how water demand for 421 irrigation changes with time, not only because of precipitation variability, but also the behavior 422 heterogeneity among farmers. Dry years show high irrigation variability between farmers as not all 423 farmers irrigate the same amounts, and wet years show much lower variability since most farmers do not 424 need to irrigate much. It is important to note that the number of active farmers in the simulation increases 425 with time which also has impacts on the variability. In the 1980s, for example, a farmer with very low 426 annual irrigation rates due to very low well yield becomes active, keeping the minimum irrigation low for 427 the rest of the simulation period. Other patterns can be found like the decrease of maximum irrigation due 


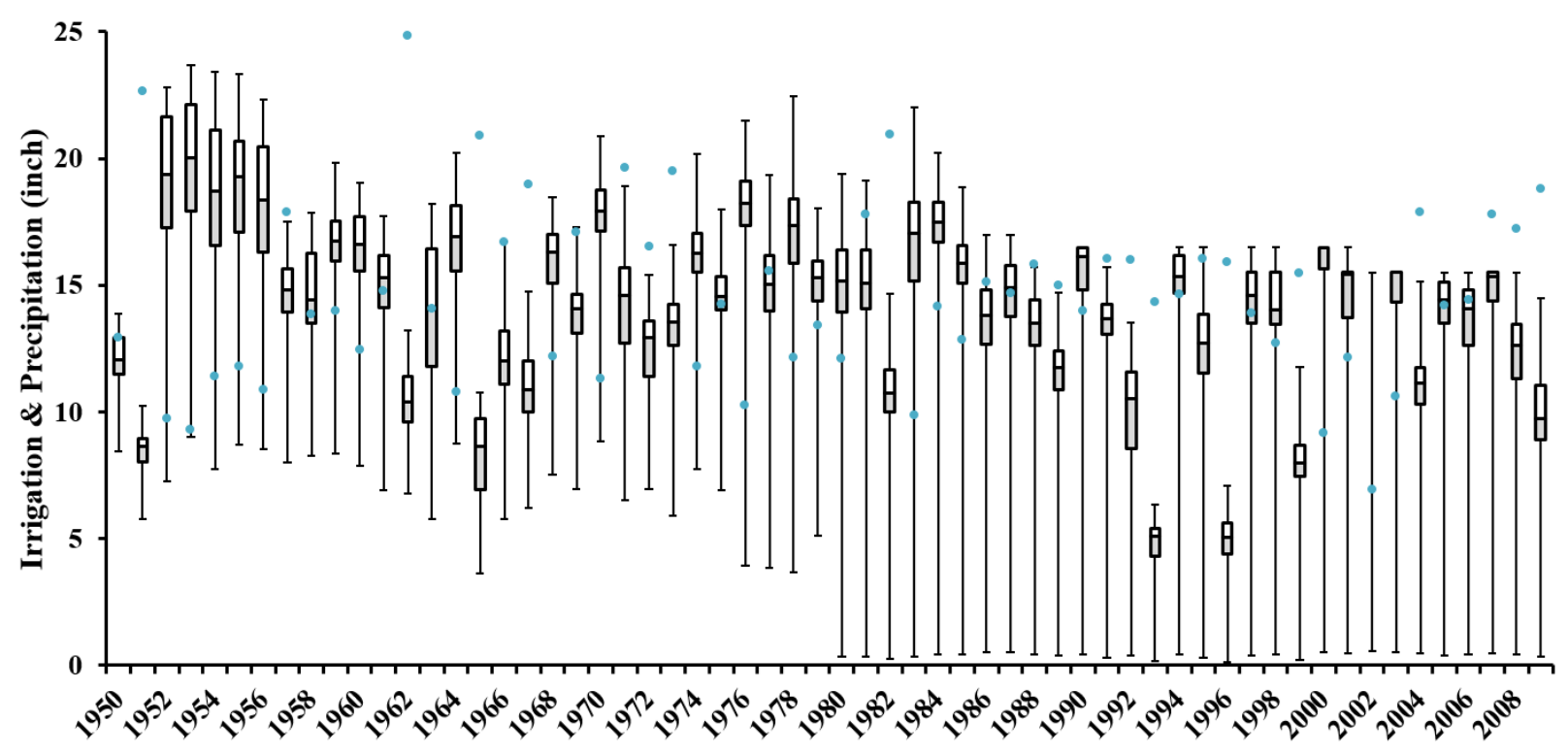

Figure 7: Box plot of annual irrigation for baseline simulation. The blue dots represent average annual precipitation in the region

\subsection{Assessing the impacts of system dynamics on individuals}

Understanding how individual behavior impacts the system is only one side of the picture; the other side lies with the impacts of system dynamics on individuals. New policies and regulations, environmental change such as decreasing water table in the aquifer, and/or climate extremes such as droughts affect the farmers in an area differently due to complex factors, including the location and size of farms, physical characteristics of the aquifer underneath a farm, annual income of the farmer, etc. Modeling at the level of the individual (i.e, a farm in this study) makes it possible to keep track of individuals and thus to understand how they interact with each other and with the environment (i.e., the aquifer and stream in this study). We explore this statement by going back to the historical simulation described in the first experiment and in the validation section of this paper. Figure 8 presents the evolution of farmers' average profit in the period of 1980-2009 compared to the average profit in the period of 1960-1980 along with the profit distribution during 1960-1980. The $\mathrm{x}$ axis shows each profit category or range, i.e. farmers making less than $\$ 40 /$ acre, between $\$ 41 /$ acre and $\$ 50 /$ acre etc. As can be 
seen, most farmers earn between $\$ 70$ and $\$ 100$ per acre from selling corn during this period and a few farmers earn less than $\$ 40$ per acre. Profit change varies monotonically with the average profit in the period. Farmers making less than $\$ 40$ per acre before 1980 see their profit decrease by over $100 \%$ after 1980 and are now making a loss. On the contrary, farmers making $\$ 110$ per acre before 1980 see their profits increase by $10 \%$ after 1980 . The overall decrease of profits resulting from the model is due to several factors. Over the 60 -year simulation, profits on wet years increase but losses on dry years increase even more. This is because the model does not account for other income sources of farmers such as crops other than corn and insurances, and it does not capture farming practices used to mitigate losses either, while it captures profit losses in dry years after 1980 with irrigation regulations and increased pumping cost due to lower water table in the aquifer. Despite the limitations, the model shows how farmers are impacted differently by regulatory change and pumping cost variability.

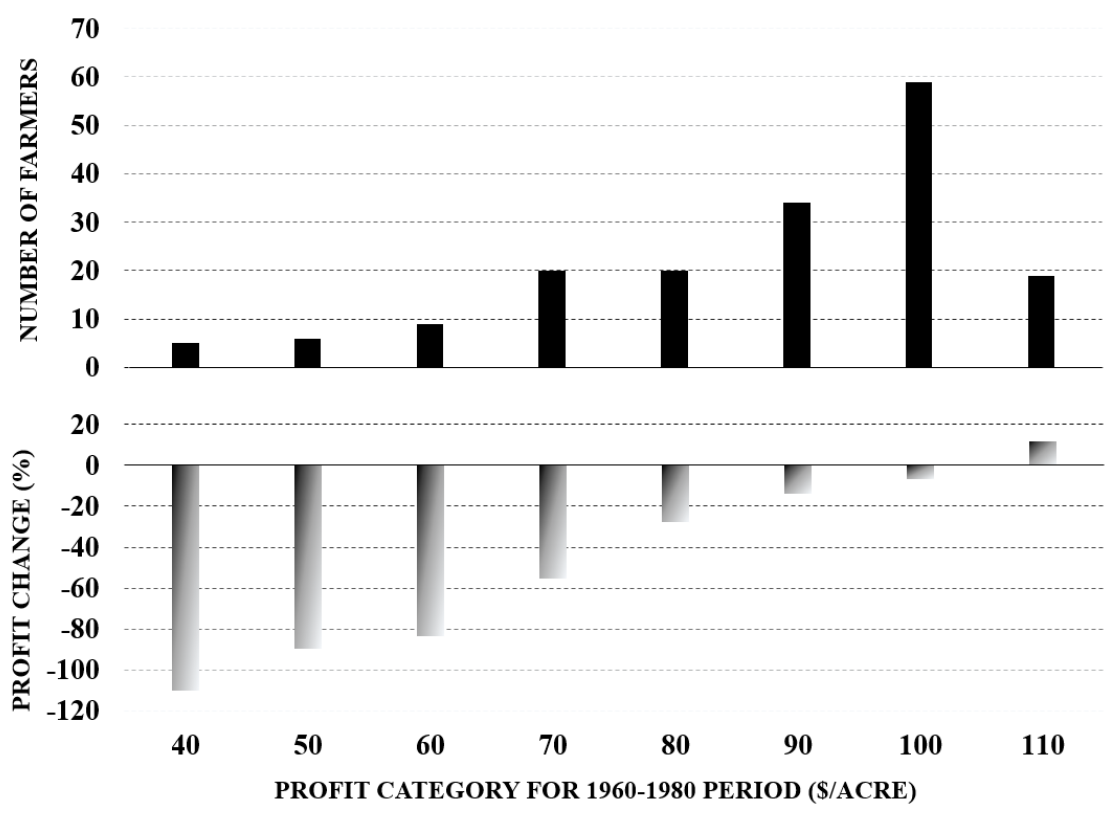

Figure 8: Number of farmers in each category of average profit between 1960 and 1980 (black bars) and change of average profit after 1980 for each category (grey bars)

Figure 9 shows the relationship between average annual irrigation and farm-level simulated drawdown. The $\mathrm{x}$ axis shows average irrigation category or range, i.e. farmers irrigating less than 9.2inch, between 9.3inch and 9.9inch etc. Most farmers irrigate on average between 14.1 and 15.5 inches annually 


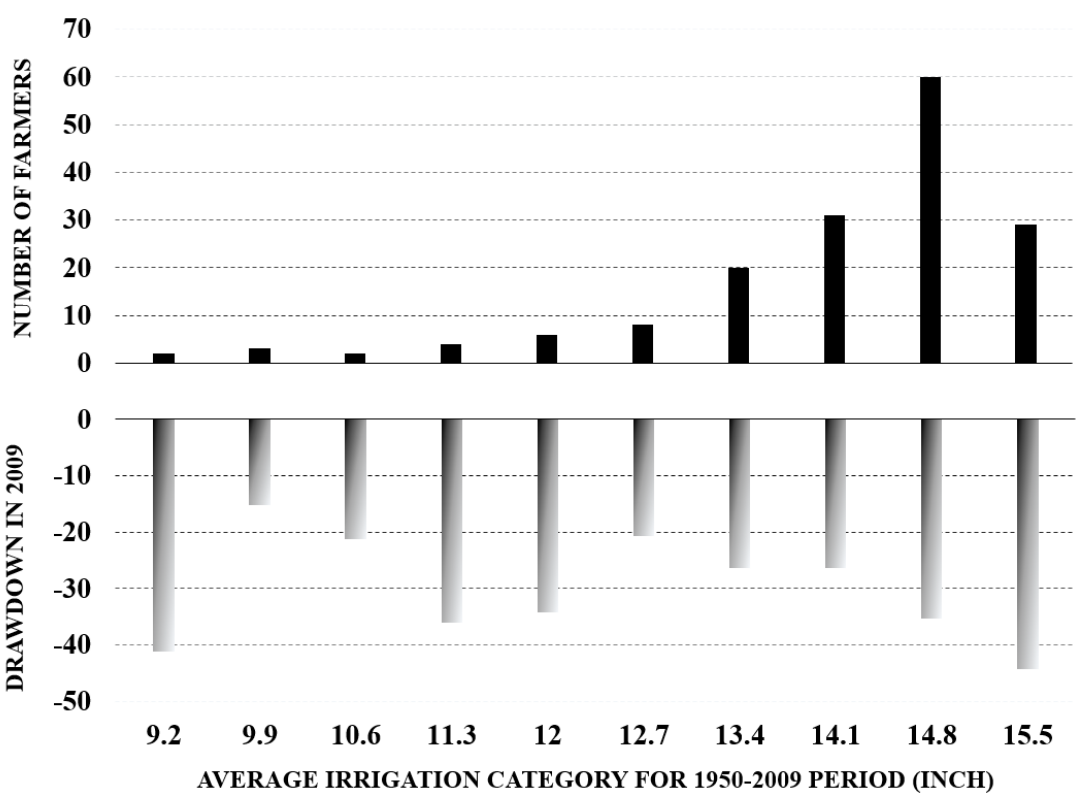

Figure 9: Number of farmers in each category of average annual irrigation over the entire simulation (black bars) and average drawdown in 2009 in each category (grey bars). The black bars show the distribution of average annual irrigation over the 60 years of simulation for all the farmers active during the entire period.

\section{4.3. The role of human behavior heterogeneity}

500 To better understand the impact of human behavior heterogeneity on the system-level 501 performance, we analyze another experiment where a set of simulations was performed with 502 heterogeneity from low to high levels, assuming a normal distribution of $S C$ with a mean value of 1.00. 503 The average profits of all farmers in the study area are plotted with increasing standard deviation of $S C$ in 504 Figure 10. 


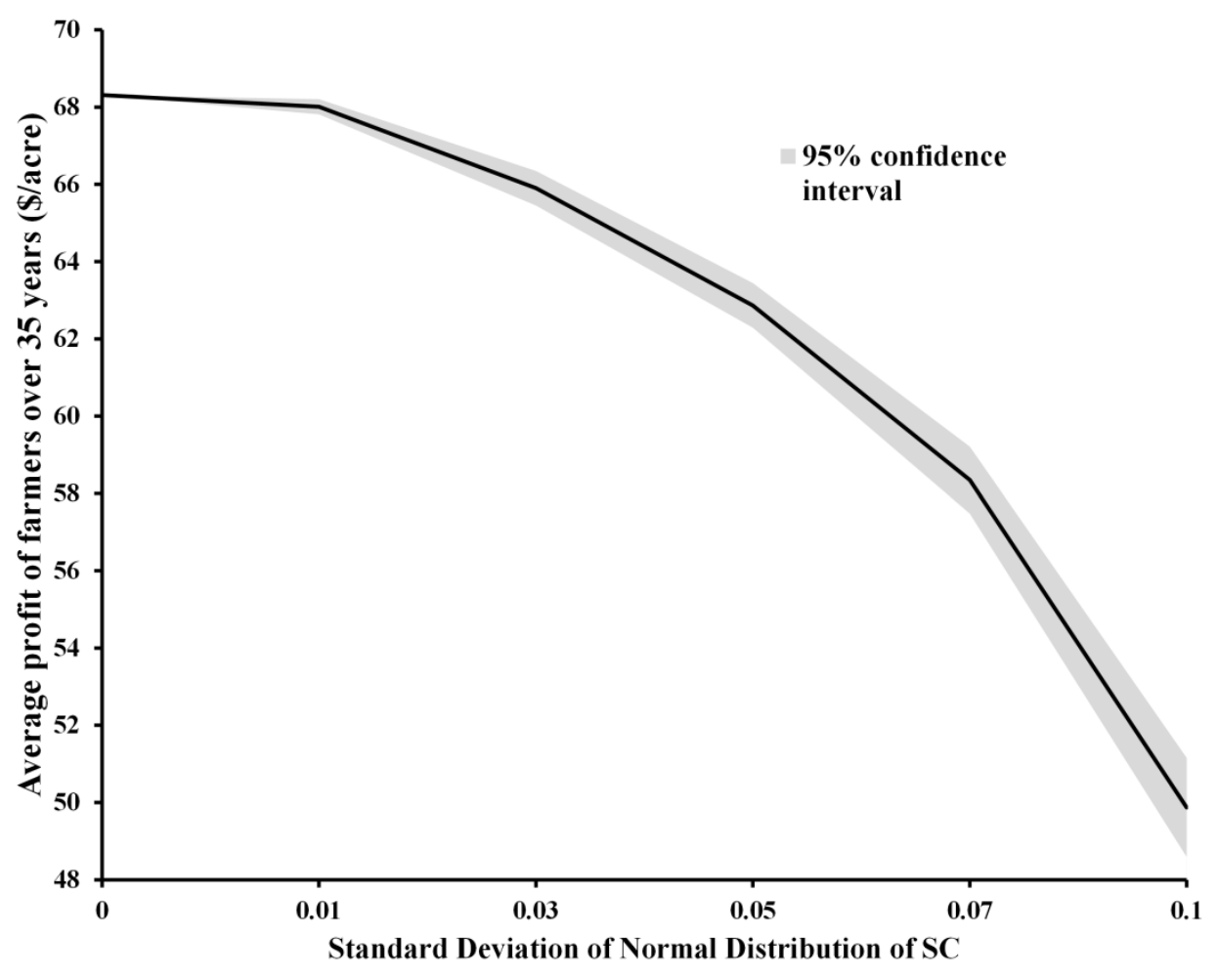

Figure 10: Average profit of all farmers in the study area as a function of behavior heterogeneity

507 As can be seen, the average profit of farmers decreases as the behavior heterogeneity increases. 508 When $S C=1.0$ for all farmers, they start to irrigate their crops when soil water deficit is exactly equal to 509 the management allowed deficit $(M A D)$. However, as heterogeneity increases, more and more farmers 510 over- or under-respond to the $M A D$ when the $S C$ value is lower or higher than 1.0. Farmers with $S C>1.0$ 511 start to irrigate when the soil water deficit is higher than $M A D$. As a result, they tend to pump less and 512 their crop yield and profit decline in response. On the contrary, farmers with $S C<1.0$ start to irrigate when 513 the soil water deficit is lower than $M A D$. Consequently, they tend to pump more and their crop yield and 514 profit may increase. However, the marginal increase of crop yield is usually less than the marginal 515 decrease given that crop yield is usually a concave function of water with diminishing marginal value 516 from increasing water use (Klocke el al., 2011). Moreover, for farmers who tend to pump more water for 517 irrigation, their actual amount of pumping may also be constrained by water use regulation (i.e., pumping 518 permit). On the other hand, nothing prevents farmers to pump less if they want to in the model. Thus, with 
less over- than under-response to crop water stress, overall, the total profit in the study area (i.e., the system-level profit) declines. Figure 10 shows that individual behavior heterogeneity generates a systematic pattern at the system level (i.e., declining profit with increasing heterogeneity). Moreover, the results here show the value of scientific knowledge if it is used to change human behavior. In particular, for the case study presented here, if the knowledge on optimal $M A D$ can be delivered to farmers in a form that they can understand and then use in their decision making, then more farmers will tend to respond to crop water stress in an appropriate way, which will reduce $S C$ deviation among farmers toward a mean value of 1.0 and thus increase crop profit at the system level (i.e., moving from right to left on the curve in Figure 10). Farmers might have various reasons for under- or over-irrigating; however, helping them to change their behavior through incentive-based policies, educational programs and innovative technologies could significantly improve both individual-level and system-level profits. For example, for the case study in this paper, the change can be achieved by assisting farmers to acquire soil moisture probes and advanced irrigation systems with variable irrigation rates.

\subsection{Behavior change through adaptations}

Human behavior changes over time. Thus to implement an ABM, one would need to specify not only the rules to represent an agent's current behavior but also the rules on how behavior rules change over time. Berry et al. (2002) and a set of associated papers from a workshop on ABM discussed some key concepts on adaptive agents, intelligence, and emergent human organization involved in agent-based modeling of a complex system. Machine learning methods have been tested to simulate agents' adaptation based on both prior knowledge and new observation, for example, Bayesian inference (e.g., Navarro et al., 2006; $\mathrm{Ng}$ et al., 2011). The psychological component of individual behavior was accounted for in a simple way in our model by assuming a normally distributed random variability in individuals' behaviors (as shown above from this study) or simply no variability as adopted in many previous studies that assume homogenous human behavior. However, human behavior is more complex and includes 
interactions between individuals and behavior change with time (i.e. learning or human intelligence ( $\mathrm{Ng}$

544 et al., 2011)).

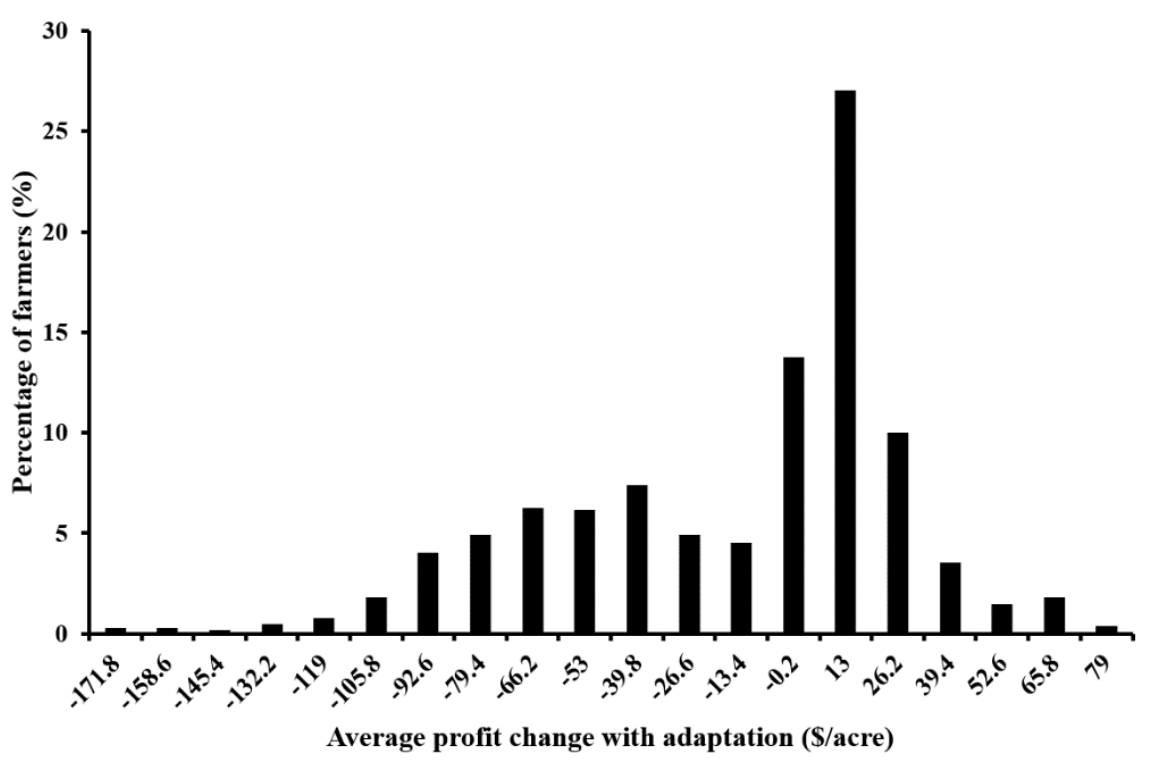

Figure 11: Profit change with behavior adaptation

In our final experiment, we integrate the change of farmers' behaviors with time in our model and

548 549 550 551 552

perform a new simulation. It is assumed that 1) farmers assess their crop yield compared to the average yield in the region every year, and they also assess their annual pumping cost subject to the average value in the region; 2) farmers with lower yield in the current year will be more sensitive to crop stress and therefore irrigate more in the following years. Equation (15) was designed to fulfill these two assumptions and shows how SC is updated year by year in the model as explained above:

$$
S C^{n+1}=S C^{n}+\min \left(\frac{C Y-0.75 \times A C Y}{A C Y}, 0\right)+\max \left(\frac{P C-1.5 \times A P C}{A P C}, 0\right)
$$

where $C Y$ is the corn yield in bushels per acre, $A C Y$ is the average corn yield over all farmers in that year in bushels per acre, and $A P C$ is the average pumping cost over all farmers in dollars per acre. $S C$ is subject to a range of reasonable values between 0.8 and 1.2 and all farmers are assigned an initial value of 1, meaning that they neither under- nor over-irrigate their crops. This equation is used to decrease $S C$ when a farmer's corn yield is lower than $75 \%$ of the average corn yield over all farmers, and to increase 
$S C$ when a farmer's pumping cost is higher than $150 \%$ of the average pumping cost over all farmers. Figures 11 and 12 illustrate the impacts of including such adaptation in the model. Figure 11 presents the 560 distribution of profit change averaged over the 60 years. Farmers' profits change when their behavior 561 changes through adaptation. Profits do not necessarily increase in the case with adaptation. This is due to 562 the fact that some farmers reduce their irrigation because of high pumping cost even though the marginal 563 value of increased yield is higher than the marginal value of decreased pumping cost. Likewise, some 564 farmers increase their irrigation because of low yield but their pumping cost might increase more than 565 their profit gain from the increased yield. Profit change appears to be highly variable with some farmers 566 losing up to $\$ 180$ per acre on average by adapting their behavior while others gaining up to $\$ 80$ per acre. 567 This high variability is caused by the relationship between profit and irrigation. Figure 12 shows that 568 there is a significant drawdown difference across the region between the historical simulation and the 569 simulation with behavior adaptation, which implies that the changes in individual behaviors over time can 570 have system-level impacts. Again, heterogeneity is present with spatial patterns of drawdown difference. 571 Four areas seem to particularly benefit from farmers' adaptive behavior. In these regions up to 16 feet of 572 water are saved in the aquifer in the simulation with adaptive behavior. These results show how additional 573 behavior heterogeneity with agents' adaptations to changes affects the environmental system, as well as 574 individual variables such as profit. These results also show that farmers' behavior change toward better 575 practices can be effective to tackle issues of streamflow and aquifer depletion. One main implication of 576 these results is that human behavior plays a crucial role in CHANS modeling and should therefore be at 577 least considered as a source of uncertainty if necessary data are available instead of being the elephant in 578 the room. 


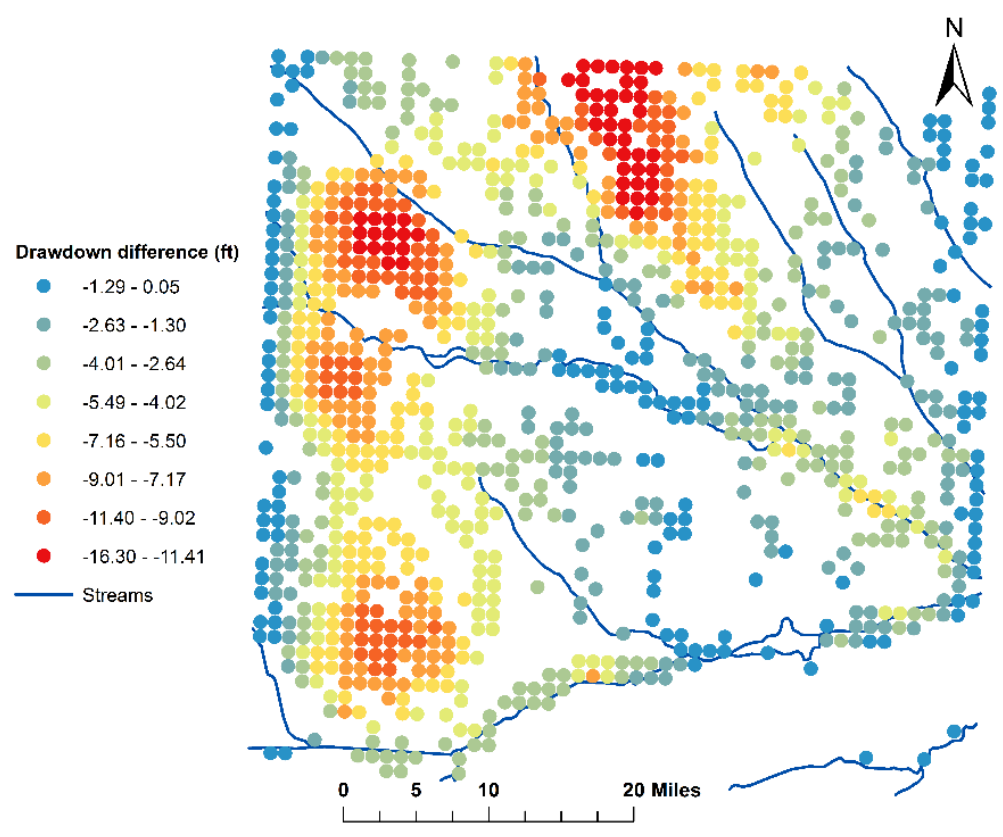

Figure 12: Drawdown difference with behavior adaptation

\section{$582 \quad$ 5. Discussion and conclusion}

583 The results presented in section 4 illustrate the role of individuals and their behavior in large584 scale groundwater-fed irrigated agriculture in the High Plains region. It appears that modeling individuals 585 in this context is important because of their influence on the system and because of the knowledge that 586 can be gained on how differently they are impacted by the systems' dynamics. While physical attributes 587 characterizing farmers' decisions on irrigation such as soil type or irrigated area can be measured and 588 easily incorporated in models, it is more difficult to incorporate the psychological or social attributes of 589 farmers' behavior in models as these attributes are hard to characterize and to quantify. However, 590 farmers' human behavior, here accounted for with the sensitivity to crop stress, seems to play an 591 important role in this system as shown on Figure 10, Figure 11 and Figure 12. Figure 6 and Figure 7 show 592 how education and information can have significant impacts in reducing streamflow and aquifer 593 depletion. In other words, institutions and regulatory agencies can use information access and educational 

programs to improve farmers' behavior as a way to mitigate environmental impacts of groundwater pumping for irrigation. These findings support current efforts at the national and international levels to improve irrigation practices and conserve decreasing water resources (English et al., 2002; Pereira et al., 2002; Schaible et al., 2012). With dropping water levels in aquifers and the looming threat of climate change, education and information diffusion can help farmers reduce their water consumption, adopt new technologies and switch to more adequate practices resulting in reduced water depletion with potential positive or negative financial impacts to keep in mind.

Using a single parameter can be seen as a limitation of the paper, especially since real values of $S C$ are not known, but we believe that using this straightforward method can provide very valuable insights and lay the work for more complex analyses in the future, as the results above illustrates. Our model for example could be improved to account for behavior heterogeneity through a more realistic distribution than the normal distribution that we used to modify farmers' preferences over crop water stress or to better account for behavior adaptation and other characteristics of human behavior.

To conclude, this paper illustrates the role of individuals, human behavior and heterogeneity in 608 modeling CHANS in the context of this case study. Results from our integrated models shed light on the 609 significant role of individuals and human behavior in creating spatial and temporal patterns within a 610 coupled human and natural system. Crop yield, profit, irrigation and groundwater depletion vary 611 considerably in time and space, even in a small region, because of physical and behavioral heterogeneity. 612 Model results also illustrate that modeling individuals allows the quantification of the heterogeneous 613 impacts of systems' dynamics on individuals. For example, farmers with lower profits might be more 614 affected by irrigation regulations or increased pumping cost than farmers with high profits; farmers with 615 low pumping rates can be negatively affected by the physical characteristics of the underlying aquifer and 616 by neighboring farmers as pumping well density is a major factor of groundwater depletion. Overall, 617 these results show the breadth of information that can be gained from considering individuals in modeling 618 CHANS. Thus averaging over all agents may provide a misleading basis for modeling unless the 
population at stake is well studied, understood and can be segmented accurately into representative groups. The importance of modeling individual differences has been addressed in psychology (e.g., Ashby et al., 1994; Navarro et al. 2006) in terms of human behaviors and in ecology (e.g., DeAngelis and Mooij, 2005) in terms of the heterogeneity of ecological agents.

In the case of the Republican River Basin, our model suggests that scientific knowledge dissemination and education programs to promote behavior change could be effective in tackling environmental issues such as groundwater and streamflow depletion while providing economic benefits, which emphasizes the complementary role of non-market methods in water demand management. Based on our results, we recommend that human behavior is at least considered as an additional source of uncertainty in modeling CHANS as it can have such a significant role in the dynamics of the coupled systems. There is much to learn from economists, social scientists and psychologists to better quantify and represent human behavior.

\section{Acknowledgments}

This work was funded by the U.S. National Science Foundation (NSF) (U.S. NSF grant EFRI083598). The authors thank three anonymous reviewers for their very helpful suggestions in revising the primary manuscript.

\section{References}

Alberti, M., Asbjornsen, H., Baker, L., Brozovic, N., Drinkwater, L., Drzyzga, S., et al. (2011). Research on coupled human and natural systems (CHANS): approach, challenges, and strategies. Bulletin of the Ecological Society of America, 92(2), 218-228.

Allen, R., Pereira, L., Raes, D., \& Smith, M. (1998). Crop Evapotranspiration, FAO Irrigation \& Drainage Paper No. 56. Rome, Italy: FAO.

An, L. (2012). Modeling human decisions in coupled human and natural systems: Review of agent-based models. Ecological Modelling, 229, 25-36.

Andales, A., Chávez, J., \& Bauder, T. (2011). Irrigation Scheduling: The Water Balance Approach. Colorado State University Extension. 
Arnold, R., Troost, C., \& Berger, T. (2014). Quantifying the economic importance of irrigation water reuse in a Chilean watershed using an integrated agent-based model. Water Resources Research, $51,648-668$.

Ashby, F. G., Maddox, W. T., \& Lee, W. W. (1994). On the dangers of averaging across subjects when using multidimensional scaling or the similarity-choice model. Psychological Science, 5(3), 144151.

Athanasiadis, I., Mentes, A., Mitkas, P., \& Mylopoulos, Y. (2005). A hybrid agent-based model for estimating residential water demand. Simulation, 81(3), 175-187.

Baggio, J. A., \& Janssen, M. A. (2013, December). Comparing agent-based models on experimental data of irrigation games. In Simulation Conference (WSC), 2013 Winter (pp. 1742-1753). IEEE.

Berger, T. (2001). Agent-based spatial models applied to agriculture: a simulation tool for technology diffusion, resource use changes and policy analysis. Agricultural economics, 25(2-3), 245-260.

Berger, T., \& Troost, C. (2014). Agent - based Modelling of Climate Adaptation and Mitigation Options in Agriculture. Journal of Agricultural Economics, 65(2), 323-348.

Berry, B. J., Kiel, L. D., \& Elliott, E. (2002). Adaptive agents, intelligence, and emergent human organization: Capturing complexity through agent-based modeling. Proceedings of the National Academy of Sciences, 99(suppl 3), 7187-7188.

Bulatewicz, T., Yang, X., Peterson, J., Staggenborg, S., Welch, S., \& Steward, D. (2010). Accessible integration of agriculture, groundwater, and economic models using the Open Modeling Interface (OpenMI): methodology and initial results. Hydrology and Earth System Sciences, 14(3), 521534.

Cai, X. (2008). Implementation of holistic water resources-economic optimization models for river basin management-reflective experiences. Environmental Modelling \& Software, 23(1), 2-18.

Castilla-Rho, J. C., Mariethoz, G., Rojas, R., Andersen, M. S., \& Kelly, B. F. J. (2015). An agent-based platform for simulating complex human-aquifer interactions in managed groundwater systems. Environmental Modelling \& Software, 73, 305-323.

Clarke, T. R. (1997). An empirical approach for detecting crop water stress using multispectral airborne sensors. Hort. Technology, 7(1), 9-16.

Colaizzi, P. D., Barnes, E. M., Clarke, T. R., Choi, C. Y., Waller, P. M., Haberland, J., \& Kostrzewski, M. (2003). Water stress detection under high frequency sprinkler irrigation with water deficit index. Journal of Irrigation and Drainage Engineering, 129(1), 36-43.

Condon, L., \& Maxwell, R. (2014). Feedbacks between managed irrigation and water availability: Diagnosing temporal and spatial patterns using an integrated hydrologic model. Water Resources Research, 50(3), 2600-2616. 
Crutzen, P. J. (2006). The "anthropocene". In Ehlers, E. \& Krafft, T. (Eds.), Earth system science in the anthropocene (pp. 13-18). Berlin Heidelberg: Springer.

DeAngelis, D. L., \& Mooij, W. M. (2005). Individual-based modeling of ecological and evolutionary processes. Annual Review of Ecology, Evolution, and Systematics, 147-168.

Elsawah, S., Guillaume, J. H., Filatova, T., Rook, J., \& Jakeman, A. J. (2015). A methodology for eliciting, representing, and analysing stakeholder knowledge for decision making on complex socio-ecological systems: From cognitive maps to agent-based models. Journal of environmental management, 151, 500-516.

English, M. J., Solomon, K. H., \& Hoffman, G. J. (2002). A paradigm shift in irrigation management. Journal of irrigation and drainage engineering, 128(5), 267-277.

Filatova, T., Verburg, P., Parker, D., \& Stannard, C. (2013). Spatial agent-based models for socioecological systems: Challenges and prospects. Environmental modelling \& software, 45, 1-7.

Foster, T., Brozović, N., \& Butler, A. (2014). Modeling irrigation behavior in groundwater systems. Water Resources Research, 50(8), 6370-6389.

Galán, J., López-Paredes, A., \& Del Olmo, R. (2009). An agent-based model for domestic water management in Valladolid metropolitan area. Water Resources Research, 45(5).

Ghulam, A., Li, Z. L., Qin, Q., Yimit, H., \& Wang, J. (2008). Estimating crop water stress with ETM+ NIR and SWIR data. Agricultural and forest meteorology, 148(11), 1679-1695.

Gluck, K., \& Pew, R. (2006). Modeling human behavior with integrated cognitive architectures: Comparison, evaluation, and validation. Mahwah: Psychology Press.

Gual, M. A., \& Norgaard, R. B. (2010). Bridging ecological and social systems coevolution: A review and proposal. Ecological economics, 69(4), 707-717.

Hanson, B., Orloff, S., \& Peters, D. (2000). Monitoring soil moisture helps refine irrigation management. California Agriculture, 54(3).

Harbaugh, A. W. (2005). MODFLOW-2005, the US Geological Survey modular ground-water model: The ground-water flow process (pp. 6-A16). Reston, VA, USA: US Department of the Interior, US Geological Survey.

Harou, J., Pulido-Velazquez, M., Rosenberg, D., Medellín-Azuara, J., Lund, J., \& Howitt, R. (2009). Hydro-economic models: Concepts, design, applications, and future prospects. Journal of Hydrology, 375(3).

Huang, Q., Parker, D., Sun, S., \& Filatova, T. (2013). Effects of agent heterogeneity in the presence of a land-market: A systematic test in an agent-based laboratory. Computers, environment and urban systems, 41, 188-203.

Irrigation and Water Management for Corn. (n.d.). Retrieved 04 20, 2015, from University of Nebraska Lincoln, Crop Watch: http://cropwatch.unl.edu/corn/water 
Jensen, M. (1968). Water consumption by agricultural plants. New York: Academic Press Inc.

715

Jorgensen, B., Graymore, M., \& O'Toole, K. (2009). Household water use behavior: An integrated model. Journal of environmental management, 91(1), 227-236.

Kelly, R., Jakeman, A., Barreteau, O., Borsuk, M., ElSawah, S., Hamilton, S., et al. (2013). Selecting among five common modelling approaches for integrated environmental assessment and management. Environmental Modelling \& Software, 47, 159-181.

Klocke, N. L., Currie, R. S., Tomsicek, D. J., \& Koehn, J. (2011). Corn yield response to deficit irrigation. Transaction of the ASABE, 54(3), 931-940.

Kremmydas, D. (2012). Agent based modeling for agricultural policy evaluation: A Review. AUA Working Paper Series No.2012-3 December 2012

Lamm, F., Rogers, D., \& Clark, G. (n.d.). Irrigation Scheduling for Corn: Macromanagement. K-State Research \& Extension.

Laniak, G., Olchin, G., Goodall, J., Voinov, A., Hill, M., Glynn, P., et al. (2013). Integrated environmental modeling: a vision and roadmap for the future. Environmental Modelling \& Software, 39, 3-23.

Lave, C., \& March, J. (1993). An introduction to models in the social sciences. Lanham: University Press of America.

Ligtenberg, A., van Lammeren, R., Bregt, A., \& Beulens, A. (2010). Validation of an agent-based model for spatial planning: A role-playing approach. Computers, Environment and Urban Systems, $34(5), 424-434$.

Liu, J., Dietz, T., Carpenter, S., Alberti, M., Folke, C., Moran, E., et al. (2007). Complexity of coupled human and natural systems. Science, 317(5844), 1513-1516.

Martin, D., Dorn, T., Melvin, S., Corr, A., \& Kranz, W. (2011, February). Evaluating energy use for pumping irrigation water. In Proceedings of the 23rd Annual Central Plains Irrigation Conference (pp. 22-23).

Merkley, G. P., \& Allen, R. G. (2004). Sprinkle \& Trickle Irrigation: Lecture Notes. Biological and Irrigation Engineering Department, Utah State University.

Miro, M. (2012). Integrating institutional and local decision-making with emergent environmental phenomena: the case of the Republican River Basin. Master's Thesis. University of Illinois at Urbana-Champaign.

Müller, B., Bohn, F., Dreßler, G., Groeneveld, J., Klassert, C., Martin, R., Schlüter, M., Schulze, J., Weise, H. \& Schwarz, N. (2013). Describing human decisions in agent-based models-ODD+ D, an extension of the ODD protocol. Environmental Modelling \& Software, 48, 37-48.

Mulligan, K., Brown, C., Yang, Y., \& Ahlfeld, D. (2014). Assessing groundwater policy with coupled economic-groundwater hydrologic modeling. Water Resources Research, 50(3), 2257-2275. 
Navarro, D. J., Griffiths, T. L., Steyvers, M., \& Lee, M. D. (2006). Modeling individual differences using Dirichlet processes. Journal of mathematical Psychology, 50(2), 101-122.

Nebraska Association of Resources Districts. (2014). Nebraska's Natural Resources Districts. Retrieved December 10, 2014, from http://www.nrdnet.org/

Nebraska Department of Agriculture. (2013, February). Nebraska Agriculture. Retrieved December 4, 2014, from http://www.nda.nebraska.gov/: http://www.nda.nebraska.gov/publications/ne_ag_facts_brochure.pdf

Ng, T., Eheart, J., Cai, X., \& Braden, J. (2011). An agent-based model of farmer decision-making and water quality impacts at the watershed scale under markets for carbon allowances and a second-generation biofuel crop. Water Resources Research, 47(9).

Noel, P. (2015). Studying Coupled Human and Natural Systems From a Decentralized Perspective: The Case of Agent-Based and Decentralized Modeling. Master's thesis, University of Illinois at Urbana-Champaign.

Pereira, L. S., Oweis, T., \& Zairi, A. (2002). Irrigation management under water scarcity. Agricultural water management, 57(3), 175-206.

Perry, C., \& Combs, L. (1998). Summary of Floods in the United States, January 1992 through September 1993. Denver, Colorado: U.S. Geological Survey.

Popelka, A. (2004). Republican River Dispute: An Analysis of the Parties' Compact Interpretation and Final Settlement Stipulation. The Nebraska Law Review, 83, 596.

Republican River Compact Administration. Retrieved 9 9, 2015, from http://www.republicanrivercompact.org/

Rhoads, F., \& Yonts, C. (1991). Irrigation Scheduling for Corn - Why and How. National Corn Handbook.

Rosegrant, M., Cai, X., \& Cline, S. (2002). World Water and Food to 2025. Washington, D.C.: International Food Policy Research Institute.

Rounsevell, M., Robinson, D., \& Murray-Rust, D. (2012). From actors to agents in socio-ecological systems models. Philosophical Transactions of the Royal Society B: Biological Sciences, 367(1586), 259-269.

Russell, S., \& Fielding, K. (2010). Water demand management research: A psychological perspective. Water Resources Research, 46(5).

Sauer, T., Havlík, P., Schneider, U., Schmid, E., Kindermann, G., \& Obersteiner, M. (2010). Agriculture and resource availability in a changing world: The role of irrigation. Water Resources Research, 46(6). 
Scanlon, B., Faunt, C., Longuevergne, L., Reedy, R., Alley, W., McGuire, V., et al. (2012). Groundwater depletion and sustainability of irrigation in the US High Plains and Central Valley. Proceedings of the national academy of sciences, 109(24), 9320-9325.

Schaible, G., \& Aillery, M. (2012). Water conservation in irrigated agriculture: trends and challenges in the face of emerging demands. USDA-ERS Economic Information Bulletin, (99).

Schlüter, M., \& Pahl-Wostl, C. (2007). Mechanisms of resilience in common-pool resource management systems: an agent-based model of water use in a river basin. Ecology and Society, 12(2), 4.

Schlüter, M., McAllister, R., Arlinghaus, R., Bunnefeld, N., Eisenack, K., Hoelker, F., et al. (2012). NEW HORIZONS FOR MANAGING THE ENVIRONMENT: A REVIEW OF COUPLED SOCIALECOLOGICAL SYSTEMS MODELING. Natural Resource Modeling, 25(1), 219-272.

Shafiee-Jood, M., Cai, X., Chen, X., Liang, X. and Kumar, P. (2014). Assessing the value of seasonal climate forecast information through an end-to-end forecasting framework: Application to U.S. 2012 drought in central Illinois, Wat. Resour. Res., 50(8): 6592-6609 doi:10.1002/2014WR015822

Sivapalan, M., Savenije, H., \& Blöschl, G. (2012). Socio-hydrology: A new science of people and water. Hydrological Processes, 26(8), 1270-1276.

Steffen, W., Persson, Å., Deutsch, L., Zalasiewicz, J., Williams, M., Richardson, K., Crumley, C., Crutzen, P., Folke, C., Gordon, L. and Molina, M. (2011). The Anthropocene: From global change to planetary stewardship. Ambio, 40(7), 739-761.

Steward, D., Bruss, P., Yang, X., Staggenborg, S., Welch, S., \& Apley, M. (2013). Tapping unsustainable groundwater stores for agricultural production in the High Plains Aquifer of Kansas, projections to 2110. Proceedings of the National Academy of Sciences, 110(37), E3477-E3486.

Szilagyi, J. (1999). Streamflow depletion investigations in the Republican River basin: Colorado, Nebraska, and Kansas. Journal of Environmental Systems, 27(3), 251-263.

Tesfatsion, L. (2003). Agent-based computational economics: modeling economies as complex adaptive systems. Information Sciences, 149(4), 262-268.

United States Department of Agriculture. (2013). United States Department of Agriculture, National Agricultural Statistics Service. Retrieved 12 4, 2014, from http://www.nass.usda.gov/Quick_Stats/index.php

van Oel, P., Krol, M., Hoekstra, A., \& Taddei, R. (2010). Feedback mechanisms between water availability and water use in a semi-arid river basin: A spatially explicit multi-agent simulation approach. Environmental Modelling \& Software, 25(4), 433-443.

Yang, Y., Cai, X., \& Stipanović, D. (2009). A decentralized optimization algorithm for multiagent system-based watershed management. Water Resources Research, 45(8). 


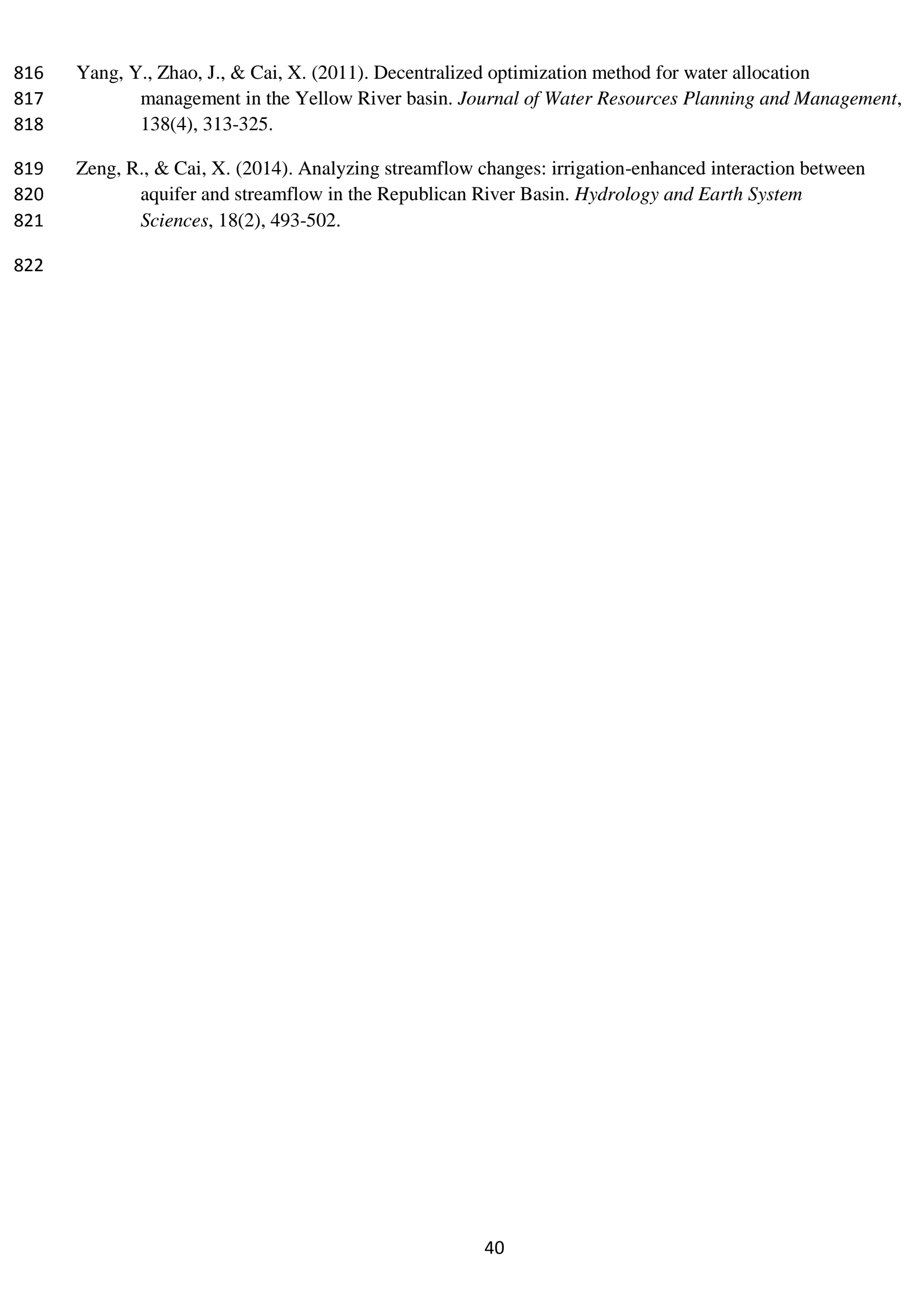

